\title{
Review \\ PPARs and Tumor Microenvironment: The Emerging Roles of
the Metabolic Master Regulators in Tumor Stromal-Epithelial
Crosstalk and Carcinogenesis
}

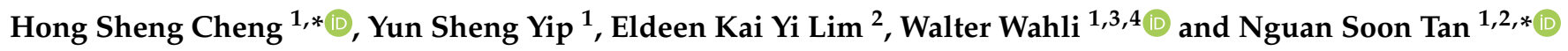

1 Lee Kong Chian School of Medicine, Nanyang Technological University Singapore, 11 Mandalay Road, Singapore 308232, Singapore; ysyip@ntu.edu.sg (Y.S.Y.); walter.wahli@ntu.edu.sg (W.W.)

2 School of Biological Sciences, Nanyang Technological University Singapore, 60 Nanyang Drive, Singapore 637551, Singapore; LI0027YI@e.ntu.edu.sg

3 Toxalim (Research Center in Food Toxicology), INRAE, ENVT, INP-PURPAN, UMR 1331, UPS, Université de Toulouse, 31300 Toulouse, France

4 Center for Integrative Genomics, Université de Lausanne, Le Génopode, CH-1015 Lausanne, Switzerland

* Correspondence: hscheng@ntu.edu.sg (H.S.C.); nstan@ntu.edu.sg (N.S.T.); Tel.: +65-6904-1295 (N.S.T.)

check for

updates

Citation: Cheng, H.S.; Yip, Y.S.; Lim, E.K.Y.; Wahli, W.; Tan, N.S. PPARs and Tumor Microenvironment: The Emerging Roles of the Metabolic Master Regulators in Tumor Stromal-Epithelial Crosstalk and Carcinogenesis. Cancers 2021, 13, 2153. https://doi.org/10.3390/ cancers13092153

Academic Editors: José I. López and Ildefonso M. de la Fuente

Received: 31 March 2021

Accepted: 26 April 2021

Published: 29 April 2021

Publisher's Note: MDPI stays neutral with regard to jurisdictional claims in published maps and institutional affiliations.

Copyright: (C) 2021 by the authors. Licensee MDPI, Basel, Switzerland. This article is an open access article distributed under the terms and conditions of the Creative Commons Attribution (CC BY) license (https:/ / creativecommons.org/licenses/by/ $4.0 /)$.
Simple Summary: The roles of peroxisome proliferator-activated receptors (PPARs) in carcinogenesis are increasingly appreciated. With the growing interest in tumor stromal-epithelial crosstalk, we aim to provide an up-to-date overview of the implications of PPARs in the tumor microenvironment. In the tumor stromal cells, the nuclear receptors exhibit critical, but functionally diverse activities, rendering it hard to ascribe either an exclusive pro- or anti-tumorigenic role for different PPAR isotypes. Based on the existing evidence, we also highlight the knowledge gaps and future prospects of targeting PPARs in the tumor microenvironment. Essentially, a PPAR-based anticancer approach holds a great deal of untapped potential, but its success relies on innovative strategies for cell-specific or tumor microenvironment-triggered drug delivery systems.

Abstract: Peroxisome proliferator-activated receptors (PPARs) have been extensively studied for more than three decades. Consisting of three isotypes, PPAR $\alpha, \gamma$, and $\beta / \delta$, these nuclear receptors are regarded as the master metabolic regulators which govern many aspects of the body energy homeostasis and cell fate. Their roles in malignancy are also increasingly recognized. With the growing interest in crosstalk between tumor stroma and epithelium, this review aims to highlight the current knowledge on the implications of PPARs in the tumor microenvironment. PPAR $\gamma$ plays a crucial role in the metabolic reprogramming of cancer-associated fibroblasts and adipocytes, coercing the two stromal cells to become substrate donors for cancer growth. Fibroblast PPAR $\beta / \delta$ can modify the risk of tumor initiation and cancer susceptibility. In endothelial cells, PPAR $\beta / \delta$ and PPAR $\alpha$ are pro- and anti-angiogenic, respectively. Although the angiogenic role of PPAR $\gamma$ remains ambiguous, it is a crucial regulator in autocrine and paracrine signaling of cancer-associated fibroblasts and tumor-associated macrophages/immune cells. Of note, angiopoietin-like 4 (ANGPTL4), a secretory protein encoded by a target gene of PPARs, triggers critical oncogenic processes such as inflammatory signaling, extracellular matrix derangement, anoikis resistance and metastasis, making it a potential drug target for cancer treatment. To conclude, PPARs in the tumor microenvironment exhibit oncogenic activities which are highly controversial and dependent on many factors such as stromal cell types, cancer types, and oncogenesis stages. Thus, the success of PPAR-based anticancer treatment potentially relies on innovative strategies to modulate PPAR activity in a cell type-specific manner.

Keywords: peroxisome proliferation-activated receptor; metabolic reprogramming; cancer-associated fibroblast; cancer-associated adipocyte; tumor-associated macrophage 


\section{Introduction}

The year 2020 marks the 30-year discovery of nuclear hormone receptor, peroxisome proliferator-activated receptors (PPARs). In 1990, the first isotype of PPAR, now called PPAR $\alpha$, was successfully cloned from the mouse liver and identified as a novel nuclear receptor that is essential for triglyceride and cholesterol homeostasis [1]. Two years later, all three PPAR isotypes, namely PPAR $\alpha, \operatorname{PPAR} \beta / \delta$, and PPAR $\gamma$, were isolated from the Xenopus laevis ovary and liver [2]. The research on PPARs has expanded exponentially ever since. Compelling evidence supports their roles as master regulators in metabolism and body energy homeostasis [3]. The clinical significance of PPARs is underscored by their synthetic ligands which are used to treat different facets of metabolic syndrome. Even before the discovery of PPARs, fibrates, which are PPAR $\alpha$ agonists, have been used as lipidlowering drugs and continue to be a mainstream therapy for atherogenic dyslipidemia and atherosclerosis [4]. Major synthetic PPAR $\gamma$ agonists, the thiazolidinediones (TZDs), are potent glucose-lowering agents that improve insulin sensitivity in adipose tissues and skeletal muscles [5]. To date, no PPAR $\beta / \delta$ ligand has been approved for clinical use. The clinical successes of TZDs and fibrates have spurred extensive development of next-generation PPAR ligands (i.e., antagonist, dual- and pan-PPAR agonists) for various metabolic complications, ranging from pre-morbid conditions such as obesity to chronic morbidities such as non-alcoholic fatty liver disease and chronic kidney disease [6]. Clearly, the discovery of PPARs underscores an important milestone in medicine, given the profound and pervasive impacts of PPARs in the way we tackle modern metabolic diseases.

The clinical impact of PPARs extends beyond metabolic disorders. To date, PPAR agonists have been trialed in many human diseases, including neurodegenerative disorders, psychiatric disorders, autoimmune and inflammatory diseases, as well as malignancies, with varying degrees of success [6,7]. PPAR-related metabolic dysregulations, such as obesity and type 2 diabetes, are independent risk factors of carcinogenesis and cancer prognosis predictors $[8,9]$. Thus, there is intense research spotlight on exploiting PPARs for cancer therapy. Early investigations revealed that, in the majority of cases, the activation of PPAR $\beta / \delta$ is linked to tumor progression, whereas PPAR $\alpha$ and PPAR $\gamma$ are associated with anti-tumorigenesis [10]. Nevertheless, existing cancer trials revealed a huge cancerto-cancer discrepancy, undermining the potential of PPAR ligands in cancer therapy [6]. Such discordance between preclinical and clinical outcomes indicates unaccounted hidden players interacting with PPARs during carcinogenesis.

It is now well-recognized that cancer cells do not live in a rigid and homogenous mass, but rather in a highly dynamic and heterogeneous community comprising a wide variety of cell types such as fibroblasts, adipocytes, immune cells, endothelial cells, pericytes, and mesenchymal stem cells, collectively known as the tumor stromal cells [11]. The interplay between tumor stromal cells and the epithelium is crucial to every step of tumorigenesis, from initiation, progression, and metastasis, besides offering enhanced plasticity and resistance to various stressors and physiological cues in cancer cells [12]. Increasing evidence also implicates a profound role for PPARs in stromal cellular behaviors and eventual consequences in cancer hallmarks. Our review aims to consolidate the current understanding of PPAR-mediated activities in carcinogenesis and tumor stromal-epithelial communication.

\section{The Roles of PPARs in Tumor Epithelium}

\subsection{Functional Diversity of PPARs in Tumorigenesis \\ 2.1.1. PPAR $\alpha$}

The three PPAR isotypes have diverse physiological functions and expression patterns in different tissues. Likewise, they also possess vastly different roles in cancer cells (Figure 1). Marked species differences are apparent in response to peroxisome proliferation induced by activated PPAR $\alpha$. Rats and mice are extremely sensitive, while humans appear to be relatively insensitive or non-responsive at dose levels that produce a marked carcinogenic response in rodents. Experimental evidence suggests a probable link between peroxisome- 
proliferator-elicited liver growth and the subsequent development of liver tumors in rats and mice. In rodents, the activation of PPAR $\alpha$ induces miRNA-mediated neoplastic changes in the liver [13]. However, these oncogenic events are not recapitulated in PPAR $\alpha$ humanized mice and human hepatocyte cell lines [14].

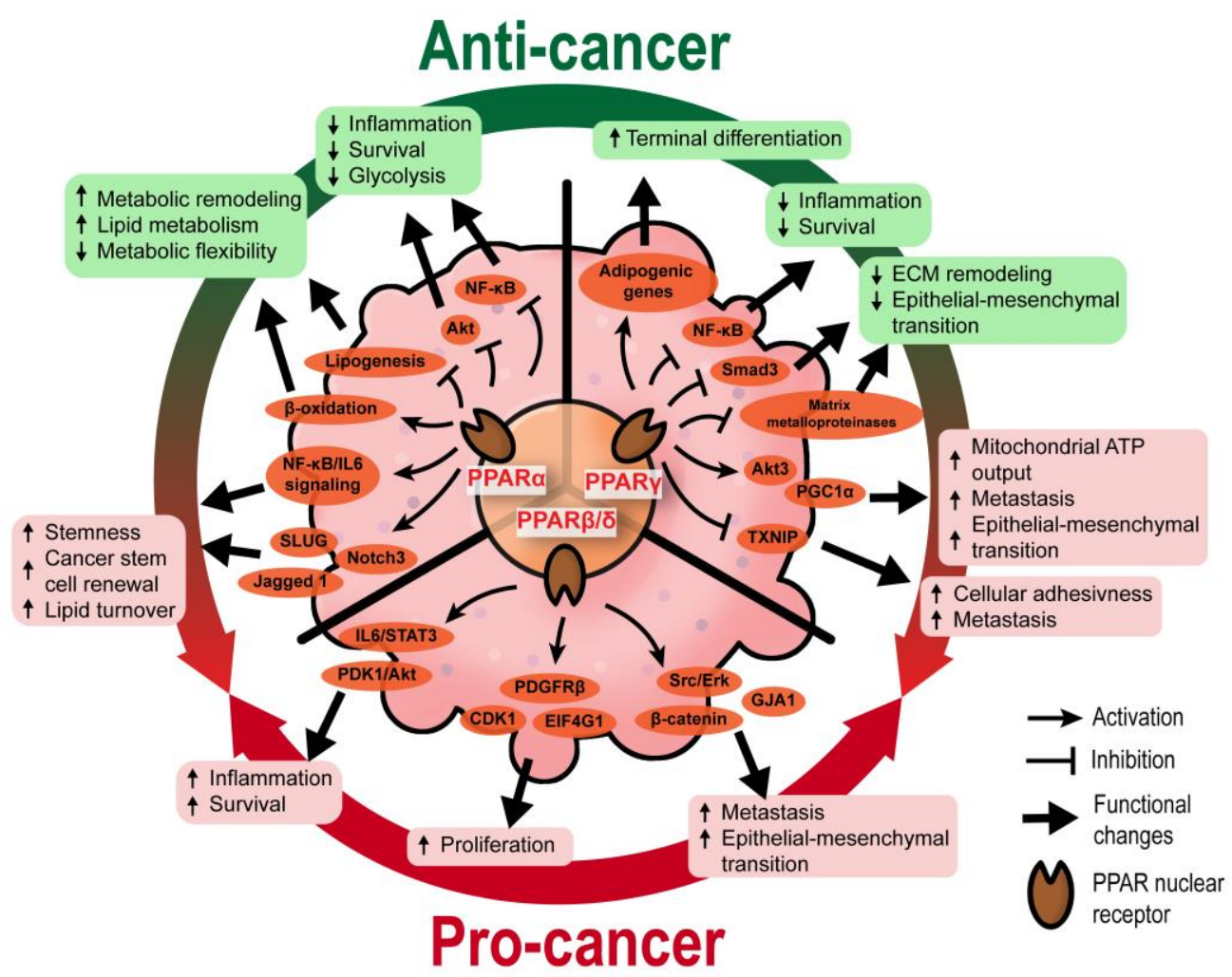

Figure 1. The cellular activities regulated by PPARs in tumor epithelium. In a tumor cell, PPAR $\alpha$ and PPAR $\gamma$ exhibit controversial roles. They are generally linked to anticancer effects (green text boxes) by impairing the pro-inflammatory, pro-metastatic, and pro-survival responses, as well as reducing metabolic flexibility. However, their pro-cancer activities (red text boxes), including the maintenance of cancer stemness, meeting high energy demands of cancers and promoting metastasis, have been reported. On the other hand, PPAR $\beta / \delta$ activates signaling pathways and key mediators implicated in pro-cancer activities such as enhanced survival, proliferation, and epithelial-mesenchymal transition. ECM, extracellular matrix.

A few studies also reported a pro-carcinogenic role of PPAR $\alpha$. In a small-scale cross sectional study ( $n=100$ patients), the overexpression of PPAR $\alpha$ in the tumor microenvironment (TME) of colorectal cancer has been linked to poorer prognosis [15]. In breast cancer stem cells, GW6471 (a PPAR $\alpha$ antagonist) is anti-proliferative and pro-apoptotic, while Wy14643 (a PPAR $\alpha$ agonist) induces the clonal expansion of breast cancer mammospheres by promoting the signaling activities of the nuclear receptor $\kappa \mathrm{B}(\mathrm{NF}-\kappa \mathrm{B}) /$ interleukin-6 (IL-6) axis, SLUG, Notch3, and Jagged 1 [16,17]. PPAR $\alpha$ signaling also ensures a high lipid turnover rate, sustaining the high energy demand to maintain stemness and self-renewal in pancreatic and colorectal cancer stem cells [18].

Based on a meta-analysis, the clinical use of fibrates, which can be traced back to the mid-1970s, does not significantly increase cancer incidence [19]. In fact, PPAR $\alpha$ activities are primarily thought to be anticancer in humans. The nuclear receptor can repress the oncogenic roles of NF- $\mathrm{kB}$ and Akt, besides forcing the tumor cells to adopt a lipo-centric metabolism $[20,21]$. Consequently, the tumor cells which adapt poorly to the PPAR $\alpha$ mediated anti-inflammatory response and enhanced fatty acid oxidation may become less proliferative and undergo apoptotic, necrotic, or autophagic cell death. 


\subsubsection{PPAR $\gamma$}

Most studies support an anti-carcinogenic role for PPAR $\gamma$, as summarized in a recent review [22]. A high expression of PPAR $\gamma$ is associated with a favorable prognosis in colorectal cancer patients [15]. The activation of PPAR $\gamma$ in cancer cells stimulates adipogenesis and disrupts the Hippo-YAP signaling pathway to force terminal differentiation and suppress proliferation [23-25]. Many cancer stem cells are also sensitive to the terminal differentiation directed by PPAR $\gamma[24,26,27]$. PPAR $\gamma$-mediated PTEN upregulation inhibits PI3K signaling to diminish the self-renewal and aggressiveness of cancer stem cells [28,29]. Furthermore, PPAR $\gamma$ agonists trigger NF- $k B$ transrepression and modulate various BCL-2 family proteins such as BAX, BAD, Bcl-XL, Bcl2, and PI3K/Akt c-Jun to exert anti-inflammatory and pro-apoptotic properties [21]. PPAR $\gamma$ agonists, ciglitazone and 15-deoxy- $\Delta 12,14$-prostaglandin J2 (15d-PGJ2), inhibited cell viability and proliferation of brain tumor stem cells at least via the inhibition of Sox 2 while enhancing Nanog expression [30]. The differential regulation of Sox 2 and Nanog by PPAR $\gamma$ agonists suggests a critical role for these stemness factors in modulating the growth and differentiation of stem cells in glioma. However, the mechanism by which PPAR $\gamma$ agonists regulate differentiation and self-renewal remains unclear. Separately, by suppressing matrix metalloproteinases and antagonizing Smad3-dependent transcriptional activity, PPAR $\gamma$ also attenuates extracellular matrix (ECM) remodeling and epithelial-mesenchymal transition (EMT), which, in turn, leads to reduced tumor metastasis [31,32].

Reports on the pro-cancer effect of PPAR $\gamma$ are not uncommon. Yang et al. (2005) [33] and Pino et al. (2004) [34] concluded that the use of PPAR $\gamma$ agonists is associated with increased cancer incidence in genetic mice models of colorectal cancer. A few studies have also described the increased risk of PPAR $\gamma$ agonists for renal and bladder cancers [35,36]. Several molecular mechanisms for the pro-cancer effect of PPAR $\gamma$ have been proposed. For instance, Galbraith et al. (2021) [37] demonstrated that in prostate cancer, PPAR $\gamma$ overexpression promoted the activity of Akt3, which subsequently inhibited a nuclear export protein, CRM1, and enhanced the nuclear retention of PPAR $\gamma$ co-activator $1 \alpha(\mathrm{PGC} 1 \alpha)$. Such activity ramps up the mitochondrial ATP output in cancer cells to meet the exorbitant energy demand for EMT and metastasis. In human melanoma, the activation of $\operatorname{PPAR} \gamma$ remodels the expression and localization of surface integrins, particularly integrin $\beta-3$ and integrin $\alpha-5$, to increase cellular adhesiveness and distal metastatic seeding [38]. These metastatic phenotypes are linked to the suppression of thioredoxin-interacting protein (TXNIP), whose expression is negatively regulated by PPAR $\gamma$ [38]. Moreover, using a liver-specific Pten knockout mouse model, it was found that Akt2 promotes the activation and pro-tumorigenic signaling of PPAR $\gamma$ by repressing hepatocyte nuclear factor $1 \alpha(\mathrm{HNF} 1 \alpha)$ [39,40]. Although multiple pro-tumorigenic mechanisms of PPAR $\gamma$ have been found, to date, there is no consensus if these PPAR $\gamma$-mediated pathways are ubiquitous in different cancer cell types. Notably, the genetic background could act as a strong modifier of the pro-tumor effect of PPAR $\gamma$, as examplified by the predisposition of certain PPAR $\gamma$ polymorphisms (i.e., Pro12Ala and C161T) to breast cancer [41]. The genetic predisposition would also explain why certain ethnic groups may be more susceptible to the cancer onset with prolonged usage of PPAR $\gamma$ agonists even though TZDs are generally associated with protective effects against several common cancers $[42,43]$.

\subsection{3. $P$ PAR $\beta / \delta$}

The dual role of PPAR $\beta / \delta$ in cancer has been thoroughly reviewed [44,45]. In summary, most of the studies are in favor of a pro-tumorigenic profile of PPAR $\beta / \delta$. Extensive investigations were focused on colon cancers [15]. Pro-tumorigenic activities of PPAR $\beta / \delta$ have been demonstrated in many colon cancer mouse models, including $\mathrm{Apc}^{\mathrm{Min} /+}$ mice [46], azoxymethane-induced colon tumors [47], colitis-associated colon cancer [48], high-fat diet or PPAR $\beta / \delta$ agonist-treated mice [49]. PPAR $\beta / \delta$ overexpression exacerbates the activation of $\beta$-catenin and several pro-invasive pathways, namely connexin 43, PDGFR $\beta$, Akt1, EIF4G1, and CDK1, to promote colorectal cancer progres- 
sion [46]. PPAR $\beta / \delta$ also positively regulates IL-6/STAT3-mediated inflammation and many pro-metastatic genes [48,50]. PPAR $\beta / \delta$ is a key mediator of PDK1-mediated mammary carcinogenesis [51]. In a nonmelanoma skin cancer mouse model, PPAR $\beta / \delta$ activates the oncogene Src and the EGFR/Erk1/2 signaling pathways upon UV exposure, resulting in increased tumor burden and EMT [52]. Enhanced response of Erk to transforming growth factor $\beta 1$ (TGF- $\beta 1$ ) is also seen in prostate cancer cells, in response to PPAR $\beta / \delta$-mediated activation of ABCA1 and caveolin-1, which results in TGF- $\beta 1$-induced tumor growth, migration, and invasion [53]. In terms of cancer stem cells, the current understanding of the role of PPAR $\beta / \delta$ is somewhat lacking. A recent study revealed that PPAR $\beta / \delta$ upregulates Nanog expression in colorectal cancer cells, promoting metastasis when exposed to a fat-enriched environment [54]; yet, another study showed its suppressive effect on SOX2 expression, thus inhibiting neuroblastoma tumorigenesis [55]. While the pro-tumorigenic role of PPAR $\beta / \delta$ in tumor epithelium is well-supported, opposite findings have also been reported [56-58]. The conflicting results suggest other still hidden mechanisms that can fine-tune the cellular activity of PPAR $\beta / \delta$ towards pro- or anticancer effects.

\subsection{Clinical Development of PPAR Modulators as Cancer Therapeutics}

The tight entanglement of PPAR signaling and tumorigenesis leads to the repurposing of PPAR-targeting drugs for cancer treatment. Many early phase clinical trials have been conducted to examine the clinical feasibility of PPAR agonists, particularly PPAR $\alpha$ and PPAR $\gamma$ agonists, against a wide range of cancers [6]. However, existing evidence does not support using any PPAR modulators to treat cancers because of underpowered study design, marginal effect size, and underwhelming outcomes. The discrepancy between preclinical and clinical results highlights a knowledge gap in our understanding of PPARs in carcinogenesis. In fact, PPAR activities may vary across different cancer types and stages. On top of that, the TME adds an extra layer of complexity to the regulatory roles of PPARs in oncogenic processes, which existing PPAR cancer research often fails to take into consideration. As PPARs may have vastly distinct roles in tumor stromal cells compared to epithelial cells during tumorigenesis, in the next section, we will provide an overview of the current understanding of PPARs in the TME and the interplay between tumor stroma and epithelium.

\section{The Roles of PPARs in Stromal Cells in the Tumor Microenvironment}

Most anticancer therapies target malignant cancer cells while largely ignoring the surrounding noncancer cell components of the tumor or TME. The TME or tumor stroma comprises nonmalignant host cellular and acellular components, including, but not limited to, fibroblasts, immune cells, endothelial cells, fat cells, and noncellular components of the tumor niche such as the basement membrane and ECM. Although most normal host cells in the stroma possess certain tumor-suppressing abilities, the stroma will change during malignancy, causing the tumor stromal cells to confer pro- or anti-tumor properties in a context- and cell type-dependent manner. Over the past decades, the role of the TME in determining every aspect of cancer progression and the efficacy of treatment has become evident. The functions of PPARs in these stromal cells are increasingly appreciated and have direct or indirect impacts on cancer progression.

\subsection{PPAR}

\subsubsection{Cancer-Associated Fibroblasts}

Cancer metabolism and bioenergetics are vastly different from those of normal epithelial cells. A high basal metabolic rate, coupled with abnormal vasculatures in the TME, poses a tremendous challenge for cancer cells to fulfill their energy demand. While the cancer cells possess remarkable plasticity and versatility to utilize various substrates to meet their demand for cellular energy, the surrounding stromal cells also play an indispensable role during cancer progression. 
Under the paracrine influences of cancer cells, stromal cells such as cancer-associated fibroblasts (CAFs) and cancer-associated adipocytes (CAAs) can transform into substrate donors to provide fuels and building blocks, namely glutamine, L-lactate, fatty acids, and ketone bodies. These metabolites are readily channeled into the Krebs cycle and oxidative phosphorylation of the cancer cells for ATP generation $[59,60]$. PPAR $\gamma$ governs many processes involved in the metabolic remodeling of stromal cells. Clinically, the expression of PPAR $\gamma$ is significantly upregulated in CAFs of cutaneous skin squamous cell carcinoma and colon adenocarcinoma [61,62]. In one study, immortalized human fibroblasts overexpressing PPAR $\gamma$ were more glycolytic, autophagic, and displayed a senescent phenotype [63]. L-lactate secretion also increased by $70 \%$ in PPAR $\gamma$-overexpressing fibroblasts compared to wild-type counterparts [63]. These PPAR $\gamma$-induced metabolic features are typical in a tumor-supporting stroma, as evidenced by accelerated tumor xenograft growth of MDAMD-231 breast cancer cells when co-implanted with transgenic fibroblasts overexpressing PPAR $\gamma$, but not with wild-type fibroblasts [63].

The hypoxic TME further aggravates the autophagic phenotype in tumor stromal cells, suggesting a modifying role of hypoxia-inducible factor $1 \alpha$ (HIF- $1 \alpha)$ in PPAR $\gamma$-dependent autophagy [63,64]. Furthermore, a study on a genetic defect (MTO1 deficiency) in mitochondria reported that AMP-activated protein kinase (AMPK) and uncoupling protein 2 (UCP2) interacted closely with PPAR $\gamma$ and HIF- $1 \alpha$, generating a HIF1 $\alpha$-PPAR $\gamma$-UCP2-AMPK axis, to influence mitochondrial bioenergetics and key metabolic processes such as glycolysis, fatty acid oxidation, and oxidative phosphorylation, leading to extensive metabolic reprogramming in fibroblasts [65]. AMPK ensures the maturation of autophagosome and lysosomal fusion during autophagy [66], besides modulating the genes responsible for mitochondrial integrity (UCP2 and PGC-1 $\alpha$ ), autophagy (BECN-1, LC3B, ATG5, ATG7, and SQSTM1), and mitophagy (PINK1, FUNDC1, BNIP3, and PRKN) [67]. The expression of AMPK target genes is considerably disrupted in fibroblasts overexpressing PPAR $\gamma$ under normoxia and hypoxia [63]. As such, the interplay among PPAR $\gamma, \operatorname{HIF} 1 \alpha$, and AMPK is pivotal in modulating CAF autophagy, but the exact mode of interaction remains largely elusive.

Following autophagy, glycolysis occurs to recycle cellular organelles and debris into basic building blocks reusable by cancer cells $[68,69]$. Many glycolytic genes are subject to PPAR $\gamma$ regulation $[70,71]$. Several studies also pointed to NF- $\mathrm{kB}$ as a key transcription factor of stromal autophagy and glycolysis [63,72], but its interaction with PPAR $\gamma$ remains elusive. In short, PPAR $\gamma$ regulates key genes and cellular events in CAFs to accomplish the metabolic coupling of tumor stroma and epithelium, essentially transforming CAFs into a powerhouse that constantly generates energetic biomolecules to support tumor growth.

In contrast to the tumor-supporting properties of CAFs overexpressing $\operatorname{PPAR} \gamma$, pharmacologic PPAR $\gamma$ activation in tumor epithelium confers anticancer effects by reducing tumor proliferation and neovascularization [63]. Thus, the activation of PPAR $\gamma$ metabolically reprograms CAFs to favor autophagic and glycolytic behaviors, allowing cancer cells to use nutrients from non-autonomous sources to sustain their uncontrolled proliferation and other activities.

\subsubsection{Cancer-Associated Adipocytes}

Like CAFs, CAAs also serve as storage sites and nutrient donors in the TME [73]. Fibroblasts and mesenchymal stromal cells readily undergo adipogenesis and differentiate into adipocytes upon exposure to adipogenic stimuli, especially the activation and upregulation of PPAR $\gamma[74,75]$. Cancer exosomes loaded with miRNA-144 and miRNA-155 facilitate the beige/brown differentiation of CAAs by modulating the MAP3K8-Erk1/2PPAR $\gamma$ axis, whereas those carrying miRNA-126 can disrupt IRS-GLUT4 signaling and promote AMPK- and HIF1 $\alpha$-mediated autophagy [76,77]. Cancer cells can also initiate the dedifferentiation of adjacent adipocytes, a process that is consistently observed when adipocytes are cocultured with cancer cells $[78,79]$. The process is characterized by the progressive loss of mature adipocyte markers such as leptin, adiponectin, HSL, and 
PPAR $\gamma$, increased expression of fibroblast markers such as matrix metalloproteinase 11 (MMP11), collagen I, and $\alpha$-SMA, as well as the adoption of a fibroblast-like morphology in the cocultured adipocytes [78,79]. These dedifferentiated adipocytes exhibit transcriptional suppression of GLUT4 and IRS1 and inhibit insulin-induced Akt phosphorylation [78]. These aberrations occur alongside the downregulation of MAP3K8-Erk1/2-PPAR $\gamma$, effectively escalating the catabolic capacity of CAAs to secrete pyruvate, L-lactate, and ketone bodies [76].

Moreover, diminished ligand activation of PPAR $\gamma$ through the constitutive expression of Notch1 induces adipocyte de-differentiation and tumor-like manifestations [80]. Treatment with rosiglitazone, a PPAR $\gamma$ agonist, effectively promoted adipocyte redifferentiation and attenuated the transformation of the adipocytes [80]. Consistent with these observations, the adipocyte-specific deletion of $P P A R \gamma$ in a chemically induced breast cancer model impaired BRCA1 expression in CAAs and subsequently accelerated tumor formation and progression [81]. Undoubtedly, PPAR $\gamma$ is a critical mediator in the cellular fate and metabolic reprogramming of CAAs. Although the actual functionality of adipocyte dedifferentiation in tumor stroma remains unclear, it is generally associated with pro-tumorigenic activities [76,78]. Furthermore, dedifferentiated adipocytes can be redifferentiated into other cell lineages, including beige/brown adipocytes that readily release bioenergetic molecules into the TME [82]. Such plasticity of adipocytes entails the possibility for tumor cells to coerce the CAAs into other tumor supportive cells.

Taken together, CAFs and CAAs are two key stromal cells that undergo extensive metabolic reprogramming to act as energy reserves for cancer epithelium, as illustrated in Figure 2. PPAR $\gamma$ signaling is implicated in the remodeling of both stromal cells, but the activity is vastly different. Autophagic CAFs are triggered by PPAR $\gamma$ activation, while PPAR $\gamma$ is suppressed in dedifferentiated CAAs. This cell type-dependent disparity highlights a need for strategies to target PPAR $\gamma$ in a cell-specific manner so that the treatment is not counter-productive.

\subsection{PPAR $\beta / \delta$ in CAFs Governs Redox Homeostasis and Affects Tumor Initiation}

The differentiation of normal fibroblasts into CAFs is one of the cornerstones of early tumor initiation in many cancer types [83,84]. CAFs can disrupt the local ECM and deliver proliferative paracrine signals to support tumorigenic events. Interestingly, mice with fibroblast-selective $P P A R \beta / \delta$ deletion developed fewer and smaller skin tumors than wild-type mice exposed to topical carcinogens [85]. Similar results were recapitulated using chemically and genetically induced intestinal carcinogenesis in these mutant mice [86], indicating that PPAR $\beta / \delta$ activity in stromal fibroblasts promotes tumor initiation. The delayed tumor emergence in the mutant mice was due to an enhanced antioxidant response in the epithelium. Mechanistically, PPAR $\beta / \delta$-knockout fibroblasts markedly increase the Nox4-derived $\mathrm{H}_{2} \mathrm{O}_{2}$ production in the adjacent epidermis, subsequently triggering an RAF/MEK-mediated NRF2 activation that elicits a strong antioxidant and cytoprotective response [85]. By reducing the phosphorylation of many tumor suppressors and oncogenes, NRF2 also increases the tumor suppressor activity of PTEN and reduces the oncogenic activity of Src and Akt, leading to delayed tumor growth [85]. Hence, reducing the expression and activity of $P P A R \beta / \delta$ in CAFs may provide a new therapeutic option to disrupt cancer susceptibility in the neighboring tumor epidermis.

Leucine-rich-alpha-2-glycoprotein 1 (LRG1) and TGF $\beta 1$ underpin a crucial process in the PPAR $\beta / \delta$-mediated stromal-epithelial crosstalk. PPAR $\beta / \delta$ in fibroblasts upregulates the expression of LRG1, which blunts the epidermal response to TGF $\beta 1$ [87]. Furthermore, exogenous LRG1 can also ablate the influence of TGF $\beta 1$ on ROS generation and NRF2 activity [85]. In colorectal carcinoma and pancreatic ductal adenocarcinoma patients, the level of LRG1 in the TME and bloodstream is significantly higher than in healthy individuals and correlates positively with a more advanced cancer stage and poorer prognosis [88-90]. This observation suggests a pro-tumorigenic role of LRG1. Surprisingly, the LRG1 promoter has two putative PPAR response elements [91]. The expression of LRG1 is increased by 
a PPAR $\beta / \delta$ agonist, GW501516, which strongly suggests that LRG1 is a direct target of PPAR $\beta / \delta$ [91]. Therefore, during the early stage of tumorigenesis, CAF PPAR $\beta / \delta$ may stimulate LRG1 expression, which interferes with TGF $\beta 1$-dependent redox homeostasis, to support a sustained oncogenic transformation in the surrounding tumor epithelium.

\section{Cancer-associated} fibroblast

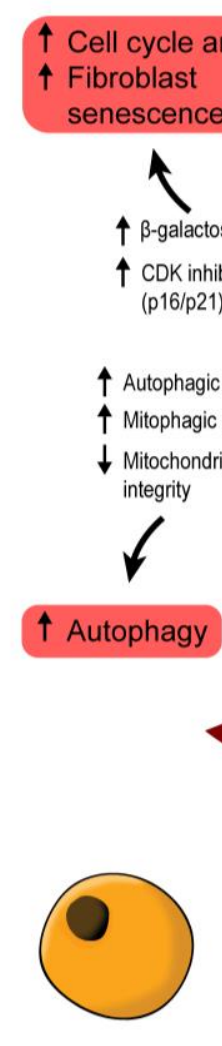

Tumor cell

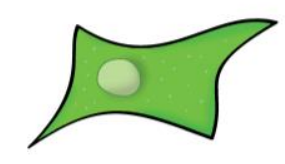

Cancer-associated fibroblast

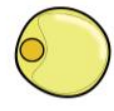

Cancer-associated adipocyte

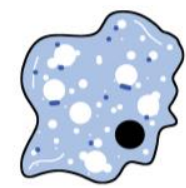

Tumor-associated macrophage/immune cells

\section{Cancer-associated adipocytes}

Figure 2. PPAR $\gamma$ orchestrates the metabolic reprogramming of cancer-associated fibroblasts and adipocytes. In cancerassociated fibroblasts (CAFs), PPAR $\gamma$ interacts closely with HIF- $1 \alpha$, AMPK, and NF- $\mathrm{B}$ to promote cell cycle arrest, senescence, autophagy, and glycolysis. These functional changes unleash many metabolic substrates into the tumor microenvironment for the neighboring tumor cells. Similarly, PPAR $\gamma$ governs the fate and function of cancer-associated adipocytes (CAAs). Upon exposure to adipogenic stimuli, PPAR $\gamma$ mediates adipogenesis and formation of CAAs to act as an energy reserve. In contrast, exposure to dedifferentiation stimuli drives CAAs to adopt a CAF-like phenotype and act as a substrate doner in the tumor microenvironment. Certain miRNAs can suppress PPAR $\gamma$ to induce brown and beige differentiation of CAAs which are also energy donors for cancer progression.

Collectively, these findings uncover a major role for stromal PPAR $\beta / \delta$ in the epithelialmesenchymal communication and cellular oxidative response in tumor development (Figure 3). Notably, this novel role of PPAR $\beta / \delta$ was primarily documented, so far, in nonmelanoma skin carcinoma and colorectal cancer models. Thus, further validation in other cancer models is necessary. 


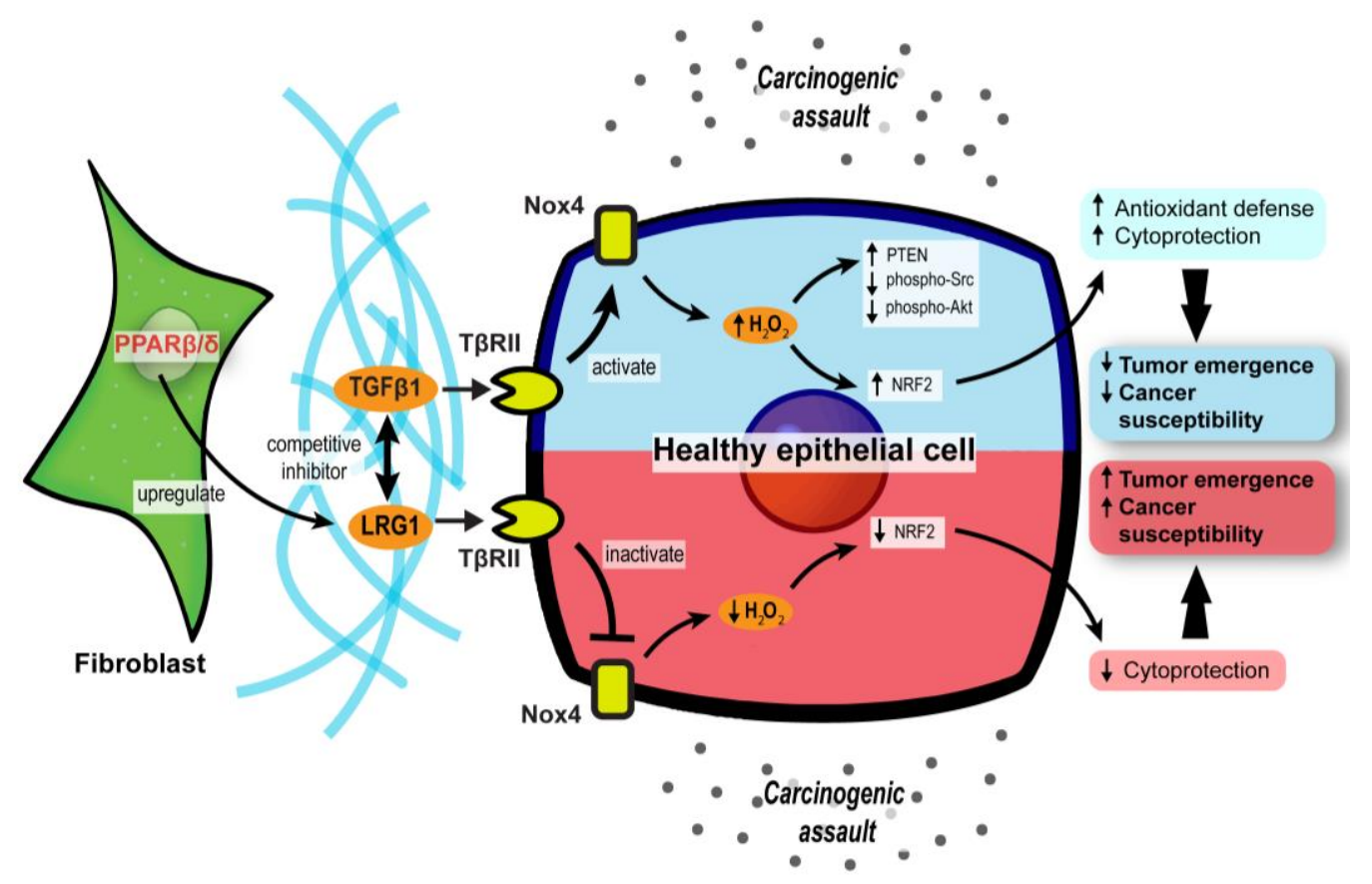

Figure 3. Stromal PPAR $\beta / \delta$ regulates epithelial redox homeostasis and oncogenesis. In carcinogenic assaults, TGF $\beta$ signaling in epithelial cells is activated to promote $\mathrm{H}_{2} \mathrm{O}_{2}$ synthesis, which subsequently activates NRF2 and reinforces the cytoprotection against carcinogens (blue upper compartment of the epithelial cell). However, fibroblast PPAR $\beta / \delta$ disrupts the protective mechanism by upregulating LRG1, which acts as a competitive inhibitor of TGF $\beta 1$ and dampens TGF $\beta$ signaling, resulting in increased cancer susceptibility and oncogenesis (red lower compartment of the epithelial cell).

\subsection{Endothelial PPARs Affect Angiogenesis in the Tumor Microenvironment}

Hypoxic regions often arise because of rapid tumor growth, which outgrows the oxygen perfusion and nutrient supply from existing vasculature [92]. Cancer cells mitigate the predicament by releasing pro-angiogenic factors that stimulate angiogenesis, which is affected by all three PPAR isotypes.

In terms of PPAR $\alpha$, synthetic PPAR $\alpha$ agonists such as fenofibrate and Wy-14643 have demonstrated suppressive effects on endothelial cell proliferation, neovascularization, and tumor xenograft growth $[93,94]$. Such anti-angiogenic effects of PPAR $\alpha$ agonists were lost in PPAR $\alpha$-deficient mice transplanted with PPAR $\alpha$-intact tumor cells, implying that PPAR $\alpha$ activation in surrounding stromal cells, but not the tumor cells, attenuated tumor angiogenesis $[93,94]$. The underlying mechanism is associated with increased anti-angiogenic factors (i.e., thrombospondin-1 and endostatin) and the interference of pro-angiogenic factor biosynthesis (i.e., VEGF-A, angiopoietin-1, and angiopoietin-2), affecting VEGFand FGF2-mediated endothelial proliferation and migration [93,95]. Furthermore, by transcriptionally suppressing the expression of endothelial P450 CYP2C epoxygenase, whose function is to catalyze arachidonic acid epoxidation, PPAR $\alpha$ also diminishes the epoxygenase products, epoxyeicosatrienoic acids, which are pro-angiogenic [96]. Thus, PPAR $\alpha$ activation in stromal endothelial cells inhibited the biosynthesis of pro-angiogenic factors while promoting the secretion of anti-angiogenic factors, thereby abrogating angiogenesis and limiting nutrient supply to attenuate tumor progression.

In contrast to PPAR $\alpha, \operatorname{PPAR} \beta / \delta$ is a pro-angiogenic nuclear receptor in line with its wound healing properties [97-99]. The activation of PPAR $\beta / \delta$ in endothelial cells by synthetic ligands or genetic manipulation consistently results in aberrant biosynthesis of VEGF, PDGFR, and c-KI, as well as accelerated endothelial cell proliferation and vascular formation $[100,101]$. In the TME, these pro-angiogenic changes stimulate the formation of a tumor with a higher vessel density, enhancing tumor feeding, oxygen provision, and metastasis capacity of the cancer cells [101]. Interestingly, in PPAR $\beta / \delta$ knockout mice 
harboring experimental wild-type tumors, the endothelial cells forming the microvessels in the tumors appear immature, hyperplastic, and less well-organized, leading to abnormal microvasculature and restricted blood flow into the tumors [102,103]. Apart from conventional growth factors, other potential PPAR $\beta / \delta$-dependent angiogenic mediators include CDKN1C [102], IL-8 [104], CLIC4, and CRBP1 [105]. Considering its regulatory effects on many angiogenic genes and the strong linkages with advanced cancer stages, tumor recurrence, and distant metastasis, PPAR $\beta / \delta$ is identified as one of the pro-angiogenic signaling hubs in cancers [103]. Thus, the pro-tumorigenic and pro-angiogenic activities of PPAR $\beta / \delta$ warrant the development of efficacious PPAR $\beta / \delta$ antagonists to be tested in cancer models.

Existing evidence on the role of PPAR $\gamma$ in angiogenesis remains ambiguous. Like PPAR $\alpha$, PPAR $\gamma$ activities in the TME are associated with the dysregulated production of angiogenic factors, especially platelet-derived endothelial cell growth factor (PD-ECGF) and fibroblast growth factor (FGF) [106,107]. Early studies generally concluded on an inhibitory effect of PPAR $\gamma$ ligands on endothelial cell proliferation in response to proangiogenic factors and endothelial tube formation [108,109], whereas subsequent investigations suggested otherwise [110,111]. Such conflicting findings may be attributable to the dosages of PPAR $\gamma$ ligands and endothelial cell types [112]. Regardless of the proor anti-angiogenic properties, VEGF/VEGFR signaling is coherently implicated in the PPAR $\gamma$-mediated effect [108-110]. A recent study using endothelial-specific PPAR $\gamma$ knockout models shed new light on the role of this nuclear receptor in angiogenesis. In mature endothelial cells, PPAR $\gamma$ knockdown impaired proliferation, migratory properties, and tubule formation capacity [111]. These impairments translated into the loss of circulating endothelial progenitor cells and angiogenic capacity in endothelial-specific PPAR $\gamma$ deficient mice, which was reversed by the transplantation of wild-type bone marrow [111] Mechanistically, abolishing PPAR $\gamma$ in the endothelial cells disrupts E2F1-mediated Wnt signaling and GSK3B interacting protein activity, resulting in suppressed endothelial proliferation [111]. Conceivably, the genetic models reinforce the pro-angiogenic activity of PPAR $\gamma$ in endothelial cells.

In short, PPAR $\alpha$ and PPAR $\beta / \delta$ exert anti- and pro-angiogenic activities in the endothelial cells of TME, respectively. On the other hand, opposing roles have been reported for PPAR $\gamma$ in angiogenesis. The roles of each PPAR isotype in angiogenesis are summarized in Figure 4. Notably, most findings on PPAR $\gamma$ are not established using oncogenic models. As the physiological cues in a TME are different from a normal condition, the true nature of PPAR $\gamma$ in cancer angiogenesis and tumor epithelium-endothelium crosstalk requires further investigation.

\subsection{PPAR-Dependent Autocrine and Paracrine Signaling}

Autocrine signaling facilities self-stimulation, while paracrine signaling allows local cell-cell communication. In the TME, both forms of cell signaling are imperative to coordinate every stage of oncogenesis, alerting the tumor cells how and when to proliferate, evade immune surveillance, escape from the existing microenvironment, and settle at a distal site. The transmission of complex messages in response to cellular stimuli is made possible by a plethora of secretory mediators, including cytokines, chemokines, growth factors, catalytic proteins, miRNAs, extracellular vesicles, and lipid compounds [113]. Many of these messengers are directly or indirectly regulated by PPARs (Figure 5). For instance, a new PPAR $\gamma$ agonist, CB13, remodels the exosomal contents from radio-resistant non-small cell lung cancer to promote endoplasmic reticulum stress and cell death via a PERK-eIF2 $\alpha$-ATF4-CHOP axis [114]. 


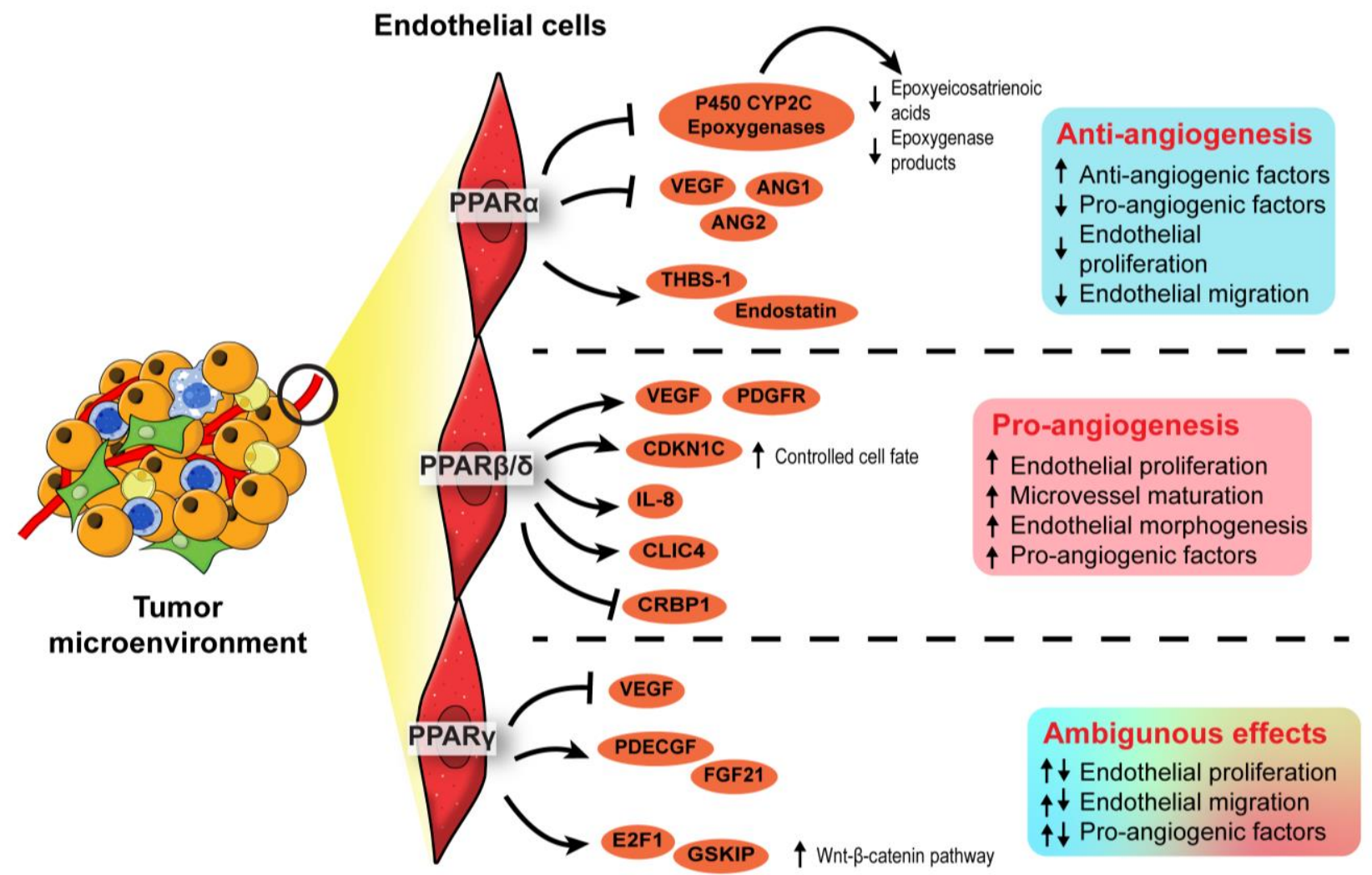

Figure 4. Angiogenic role of PPARs in endothelial cells. In the endothelial cells, PPAR $\alpha$ exhibits an anti-angiogenic effect by inhibiting endothelial proliferation, whereas PPAR $\beta / \delta$ appears pro-angiogenic by ensuring proper endothelial morphogenesis and vascular maturation. The role of PPAR $\gamma$ in angiogenesis is conflicting and warrants further investigation.

\subsubsection{Disruption of Pro-Tumor Signaling by PPAR $\gamma$ in CAFs}

Eicosanoids, which are lipid signaling molecules and cognate ligands of PPARs, are the main drivers of PPAR activation in the TME. Major eicosanoid subfamilies include prostaglandins, thromboxanes, leukotrienes, and epoxygenated fatty acids, among which the prostaglandins are the most well-investigated. In colon cancers, cyclooxygenase- 2 (COX-2), an enzyme that catalyzes the conversion of arachidonic acid to prostaglandin $\mathrm{H} 2$ ( $\mathrm{PGH} 2$ ), is overexpressed in CAFs surrounding colon adenocarcinomas, leading to a buildup of intratumoral PGE2 [61,115]. However, the resultant activity of PPARs varies across different stromal cells. For instance, 15d-PGJ2 activates PPAR $\gamma$ and suppresses the proliferation of CAFs and expression of the ECM remodeling enzyme, MMP2 [116]. By inhibiting NF- $\mathrm{KB}$, TZD-activated PPAR $\gamma$ substantially lowers the expression of proinflammatory, pro-angiogenic, and pro-metastatic signaling molecules in CAFs, including IL-6, IL-8, CXCR4, MMP2, and MMP9, which further dampens pro-tumor crosstalk in the TME $[117,118]$. The repression of PPAR $\gamma$ activity also disturbs the quiescent state of hepatic and pancreatic stellate cells, compelling their differentiation into CAFs with highly aggressive phenotypes and inducing desmoplasia in the TME [119-122]. Despite some conflicting results [123], PPAR $\gamma$ in CAFs can disrupt pro-tumorigenic paracrine signaling by suppressing the liberation of cytokines and chemokines. 


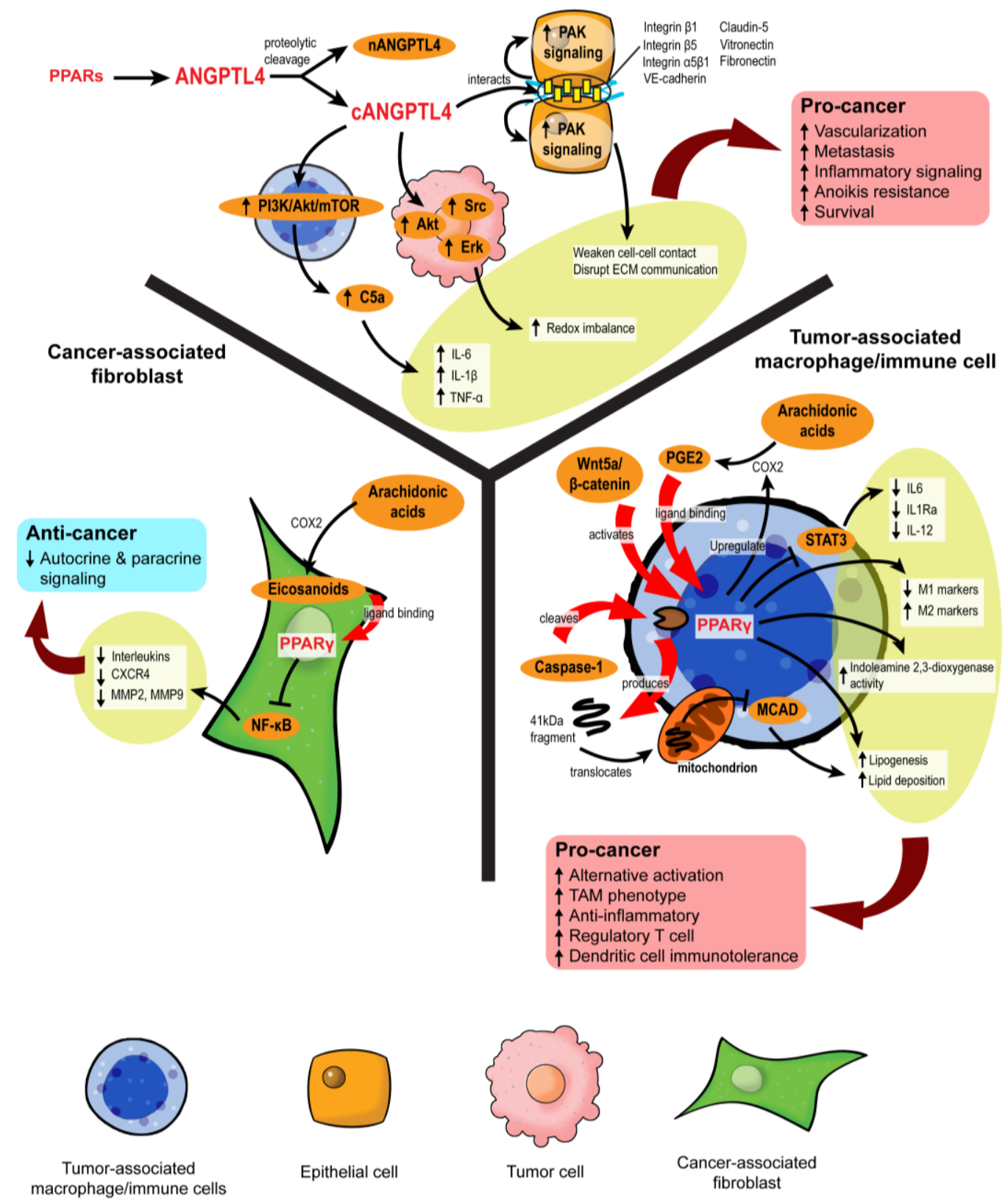

Figure 5. PPARs modulate stromal-epithelial crosstalk in the tumor microenvironment. PPARs affect autocrine and paracrine signaling in different stromal cells. In cancer-associated fibroblasts, PPAR $\gamma$ activation upon ligand binding represses NF- $\mathrm{kB}$, alleviating the secretion of many autocrine and paracrine signals. However, in macrophages and immune cells, PPAR $\gamma$ activation is primarily linked to pro-cancer activities, such as the formation of tumor-associated macrophages (TAMs), increased regulatory T cells, and immunotolerance. ANGPTL4 is a target gene product of PPARs. Proteolytic cleavage of full-length ANGPTL4 yields nANGPTL4 and cANGPTL4 domains, of which the latter is a potent paracrine signal and key mediator of inflammatory signals, anoikis resistance, and metastasis.

\subsubsection{PPAR $\gamma$ Propels the Formation of Tumor-Associated Macrophages}

The role of PPARs in innate and adaptive immune cells has been extensively studied. Unlike CAFs, the activation of PPAR $\alpha$ and PPAR $\gamma$ in macrophages favors an antiinflammatory tumor-associated macrophage (TAM) phenotype [124,125]. Classical PPAR $\gamma$ ligands, namely rosiglitazone, $\mathrm{N}$-docosahexaenoyl ethanolamide, and $\mathrm{N}$-docosahexaenoyl serotonin, effectively block paracrine signals from cancer cells to sway the fate of macrophages to adopt alternative activation and reduce their STAT3-mediated pro-inflammatory response [125]. In macrophages challenged with pathogens, WY14643 
(PPAR $\alpha$ agonist) and 15d-PGJ2 (PPAR $\gamma$ agonist) tip the balance towards the M2 phenotype by enhancing the expression of arginase I, Ym1 (chitinase 3-like 3), mannose receptor, TGF$\beta$ and increasing phagocytic capacity while diminishing M1 macrophage biomarkers [126]. $\operatorname{PPAR} \gamma$ antagonists and macrophage-specific PPAR $\gamma$ ablation attenuate these effects, clearly outlining the dependency of TAM differentiation on PPAR $\gamma[127,128]$.

Mechanistically, PPAR $\gamma$ agonism promotes lipid retention, lipogenesis, and PGE2 secretion in macrophages. The lipid metabolic changes are partly mediated by the Akt/mTOR pathway [129]. On top of its role as a nuclear receptor and transcription factor, PPAR $\gamma$ is subject to cleavage by caspase- 1 to yield a $41 \mathrm{kDa}$ fragment that translocates to mitochondria and inhibits medium-chain acyl-CoA dehydrogenase (MCAD). Such a non-canonical peptide-protein interaction can inhibit fatty acid oxidation, further aggravating lipid droplet accumulation and TAM formation [130]. Likewise, in dendritic cells residing in the TME, PPAR $\gamma$ activation directed by Wnt5a/ $\beta$-catenin paracrine signaling disrupts fatty acid oxidation and indoleamine 2,3-dioxygenase- 1 activity, subsequently leading to the generation of regulatory $\mathrm{T}$ cells, immunotolerance, and weakened immunotherapy response [131]. These PPAR $\gamma$ activities create a "friendly" TME for cancer survival, which also coincides with the functional trajectory of macrophage PPAR $\beta / \delta[132,133]$.

Nonetheless, some findings support counterarguments. For example, Cheng et al. (2016) [134] identified macrophage PPAR $\gamma$ as a key tumor suppressor and TAM modulator by abolishing Gpr132 expression. Van Ginderachter et al. (2006) [135] agreed that PPAR $\gamma$ was highly expressed in TAMs, but further stimulation with synthetic and natural ligands could sabotage TAM-induced cytotoxic T lymphocyte suppression to confer an anti-tumor effect. The overexpression of PPAR $\gamma$ in macrophages promotes the upregulation of PTEN, which is encapsulated in exosomes. The uptake of these macrophage-derived exosomes by adjacent cancer cells inhibits Akt, p38 MAPK, and migratory properties [136]. Many eicosanoids are also packaged in these exosomes to achieve paracrine stimulation of PPAR $\gamma$ and augment the inhibitory effect on tumor EMT [136].

Taken together, PPAR $\gamma$ acts as a master immuno-metabolic switch in immune cells that govern their fate and tumor-supporting role. Current consensus depicts that PPAR $\gamma$ exhibits a pro-tumorigenic effect in immune cells by promoting alternative activation, which contradicts its anticancer properties in tumor epithelium and CAFs. On the other hand, the related information on other PPAR isotypes in this aspect is somewhat limited. Interestingly, a recent study unveiled that fatty acid-enriched cancer exosomes markedly activate PPAR $\alpha$ in tumor-infiltrating dendritic cells, resulting in mitochondrial overdrive and impaired dendritic cell-mediated $\mathrm{CD} 8^{+}$cytotoxic T-cell priming [137]. These exciting findings strongly suggest an immuno-metabolic regulatory role of PPAR $\alpha$ in the TME similar to PPAR $\gamma$. Such a novel activity of PPAR $\alpha$ warrants further investigation.

\subsubsection{Role of ANGPTL4 in Stromal-Epithelial Crosstalk}

Growing evidence suggests a role of angiopoietin-like 4 (ANGPTL4) in cancer and stromal-epithelial communication. ANGPTL4 is a secretory protein that belongs to a family of ANGPTL proteins that share high amino acid sequence similarity with the angiopoietin (ANG) family $[138,139]$. Its expression is regulated by all three PPAR isotypes and PGE2, especially during major metabolic challenges such as starvation and hypoxia [139-141]. The native full-length ANGPTL4 can undergo proteolytic cleavage to yield C-terminal (cANGPTL4) and N-terminal (nANGPTL4) chains, each with distinct biological activities [142]. The nANGPTL4 domain is primarily responsible for lipid and glucose metabolism, while the cANGPTL4 domain is closely linked to tumorigenic activities, notably angiogenesis, anoikis resistance, and metastasis [143]. Thus, we will be focusing more on the cANGPTL4 fragment.

High expression of ANGPTL4 has been reported in ovarian, urothelial, and breast tumor biopsies, particularly in the CAAs [144-146]. The ANGPTL4 overexpression in CAAs is directed by IL-1 $\beta$ from neighboring TAMs with activated NLRC4 inflammasome and can be exacerbated by tumor hypoxia [147], resulting in cANGPTL4 aggregation in 
the TME. The cANGPTL4 interacts with integrins $\beta 1, \beta 5, \alpha 5 \beta 1$, VE-cadherin, and claudin-5 to induce PAK signaling and weaken cell-cell contacts [148,149]. Moreover, it also disrupts cell-ECM communication through its interaction with vitronectin and fibronectin [150]. The destabilization of cell junctions is then translated to greater intratumoral vascularization and migratory capacity of the malignant cells [151-153].

By manipulating redox homeostasis and activating several pro-survival mechanisms such as FAK/Src, PI3K/Akt, Erk signaling, ANGPTL4 markedly sharpens the resilience of tumor cells and confers anoikis resistance [154-156]. Our latest report showed that exogenous ANGPTL4 activates macrophages and induces hypercytokinemia via PI3K/Aktmediated complement component 5a (C5a) activation [157]. This finding indicates a modifying role of ANGPTL4 in TAM functionality and paracrine signaling in the TME. Thus, ANGPTL4 may act as a powerful autocrine and paracrine signaling effector of PPARs that can shape a supportive environment for cancer progression. Further investigations on the therapeutic feasibility of targeting ANGPTL4 are warranted.

\subsection{Stromal PPAR $\gamma$ Modulates Tumor Metastasis}

Only a handful of studies have investigated stromal PPAR activities on metastasis, and the results are conflicting. In myeloid-derived suppressor cells (MDSCs), deficiency of lysosomal acid lipase (lal $\left.{ }^{-/}\right)$impaired the production of PPAR $\gamma$ ligands, which led to reduced PPAR $\gamma$ activity, ROS accumulation, and mTOR-mediated tumor metastasis [158]. Following intravenous injection of B16 melanoma cells, increased lung metastases were observed in mice with myeloid-specific PPAR $\gamma$ knockout, further reinforcing the role of MDSCs' PPAR $\gamma$ in metastasis. Contradictorily, a PPAR $\gamma$ agonist, pioglitazone, has been shown to promote alternative activation of macrophages in the TME [159]. These protumorigenic myeloid cells can synthesize TGF $\beta 1$ to promote EMT of surrounding tumor cells [160]. Although the true role of stromal PPAR $\gamma$ in metastasis remains debatable, a recent study showed that astrocytes liberate polyunsaturated fatty acids, which are PPAR $\gamma$ agonists, to promote the extravasation of circulating cancer cells into the brain while PPAR $\gamma$ antagonists can reduce brain metastatic burden in vivo [161]. Astrocyte-cancer cell communication is also mediated by TGF- $\beta 2$ and ANGPTL4, the latter of which is an effector of PPARs [162]. Hence, PPAR $\gamma$ may serve as a nutritional cue to provoke the invasion of metastatic cells into a nutrient-rich environment. The results also argue for the potential use of PPAR $\gamma$ blockade to treat brain metastasis.

\section{Knowledge Gaps and Prospects of Targeting PPARs in Tumor Stroma \\ 4.1. Pressing Questions in Current PPAR Cancer Research Paradigm}

Our understanding of the role of PPARs in cancer and the TME has expanded exponentially in the past decade. As the master switch of metabolism, PPARs and their actions are deeply rooted in key tumor-supporting cells in the TME, namely CAFs, CAAs, endothelial cells, and immune cells. However, the outcomes of PPAR manipulation are not always consistent. Disagreements and even conflicting experimental results between different stromal cells are not unusual $[63,120,125]$. The high context dependency remains a puzzle and, to date, no hypothesis can substantially address the variations.

To explain the disparate findings, Youssef and Badr (2011) [163] put forward three postulations: (i) off-target effects of PPAR ligands, (ii) diverse pharmacokinetic properties of PPAR agonists, and (iii) cancer stage-dependent effect, of which the first two focus on the intrinsic characteristics of the synthetic PPAR ligands while the last one is linked to the biological context of the TME. Undeniably, synthetic ligands that are supposed to target the same PPAR isotype do not always have comparable efficacy, off-targets, turnover rate and toxicities [164]. Hence, PPAR-independent activities on the carcinogenesis caused by the non-specificity of the PPAR modulators cannot be eliminated. However, many functional studies of PPAR in the TME were also reinforced by results from genetically knockout models $[85,111,127,128]$. Therefore, the pharmacodynamic and pharmacokinetic variations of synthetic PPAR ligands may not fully account for the observed discrepancies. 
We believe that the controversial roles of PPARs in carcinogenesis should also have underlying biological rationales. One overlooked aspect is the crosstalk between PPARs and other nuclear receptors in different cancer types and stages. Classically, all PPAR isotypes form heterodimers with RXR to coordinately modulate their target genes [165]. Nonetheless, PPARs can cooperate with other nuclear receptors such as glucocorticoid receptors, estrogen-related receptors, and photoreceptor-specific nuclear receptors to form atypical heterodimers transiently [166,167]. These atypical heterodimers may regulate the expression of different sets of genes from those of the classical heterodimers, leading to diverse cell fate and behaviors [167]. The fact that the atypical heterodimers are not commonly detected suggests that the protein-protein interaction is labile and can only be stabilized with a unique combination of physiological cues, microenvironment, bioavailability of the co-factors and cognate ligands. The striking intra- and inter-heterogeneity of the TME, coupled with numerous unorthodox cellular activities, may be adequate to accomplish all sorts of stringent biological environments necessary for the stabilization of different PPAR-dependent atypical heterodimers. Such a flexible and highly amendable transcriptional regulatory mechanism mediated by PPAR-nuclear receptor collaboration may answer some of the disparities observed in PPAR cancer research. Nonetheless, the concept remains highly speculative. While it may explain the context-dependency of the PPAR-related carcinogenic roles, the real challenge is to experimentally capture the transient heterodimers and dissect their endogenous biological activities [167]. Nevertheless, the ability to rewire the non-canonical nuclear receptor crosstalk in the TME may offer a new therapeutic strategy in oncology considering the marked druggability of most nuclear receptors.

Another pitfall in PPAR cancer research is that current drug development and research attention highly skew towards PPAR $\alpha$ and PPAR $\gamma$. Our knowledge on PPAR $\beta / \delta$ and choices of PPAR $\beta / \delta$-targeting drugs is comparatively limited. Yet, unlike PPAR $\alpha$ and $\operatorname{PPAR} \gamma, \operatorname{PPAR} \beta / \delta$, which is ubiquitously expressed in almost all tissues, displays an apparent pro-tumor activity. Hence, potent PPAR $\beta / \delta$ antagonists may offer some fruitful outcomes in cancer treatment.

\subsection{Future Prospects and Strategies to Target Stromal PPARs for Precision Oncology}

Owing to the controversial roles of PPAR in the TME, the success of PPAR-based anticancer treatment potentially relies on innovative strategies for cell-type-specific drug delivery or TME-triggered drug release systems [168] (Figure 6). In this context, exosomes are excellent candidates to be developed into precise drug carriers. They are naturally occurring, hence exhibiting remarkable biocompatibility and bioavailability with limited immunogenicity [169]. Furthermore, by modifying the membrane protein compositions, exosomes have shown excellent specificity to recognize a selected protein [170] or cell type [171]. They also possess high drug loading and unloading capacity [172]. The phospholipid bilayer effectively contains the cargo from systemic drug release [169]. These striking features of exosomes allow them to be used as a targeted drug delivery system for pharmacotherapy. In fact, exosomes loaded with natural PPAR ligands such as fatty acids and eicosanoids are easily internalized, leading to high intracellular retention of the biomolecules $[136,137,173]$. Therefore, by carefully selecting the membrane protein targets of the exosomes, it may become possible to achieve stromal-specific administration of PPAR agonists or antagonists.

Recent advancements in TME-responsive drug release with nanoparticles are remarkable [174]. Unlike exosomes, which depend on membrane proteins to promote targeted delivery, the TME-sensing moieties of nanoparticles are usually based on physico-chemical alterations of the TME such as acidic $\mathrm{pH}$, redox imbalance, high ATP and the enrichment of extracellular enzymes (MMPs and $\beta$-galactosidases) or paracrine signals (PDL-1) [174]. Nanoparticles of about $100 \mathrm{~nm}$ in diameter demonstrate desirable cellular uptake, and for deep tumor penetration, nanoparticles smaller than $30 \mathrm{~nm}$ should be used [175]. Superparamagnetic iron oxide nanoparticles functionalized with conjugated linoleic acid 
have been shown to increase PPAR $\gamma$ activity, subsequently triggering necrotic cell death in cancer cells [176]. Clearly, the nanoparticle-mediated delivery of PPAR ligands is a viable anticancer strategy. By incorporating different combinations of TME-sensing moieties within a single carrier, we can fabricate multi-sensing nanocarriers which execute drug release only when a specific cell type or set of physiological conditions is met [174]. However, singularly targeting one stromal cell type is not sufficient. For example, fibroblast activation protein- $\alpha$ (FAP) is a transmembrane prolyl endopeptidase highly expressed in CAFs [177]. Sibrotuzumab, a FAP-neutralizing antibody, failed to achieve even one complete or partial remission in a phase II trial involving 25 patients with metastatic colon cancer [178]. Another phase II trial with talabostat, a small molecule inhibitor of FAP, also yielded disappointing patient outcomes [179].

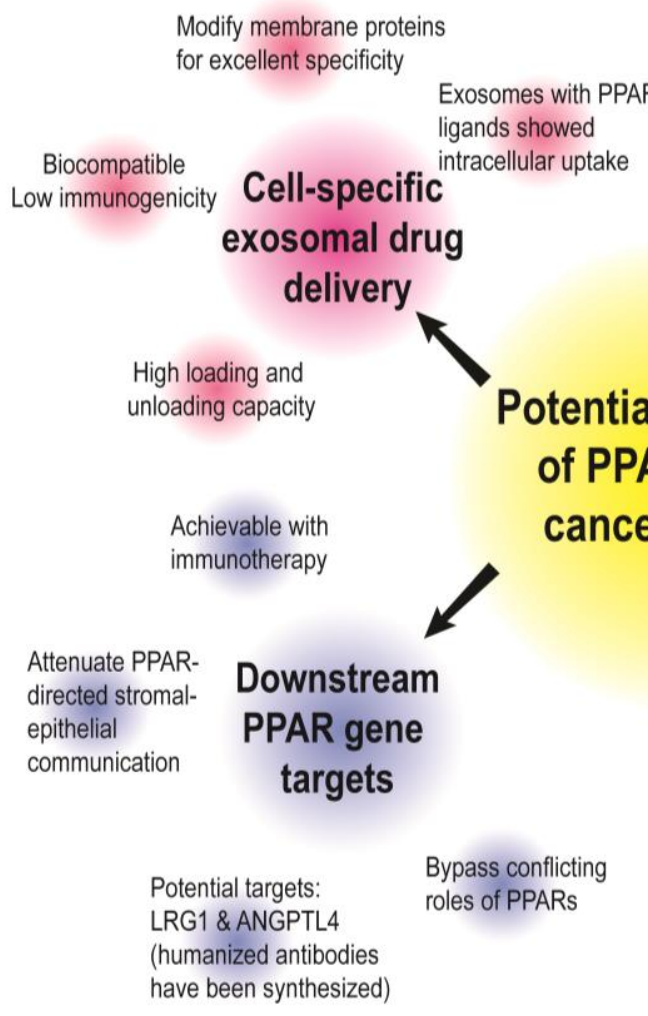

Combine several sensing moieties

to improve specificity

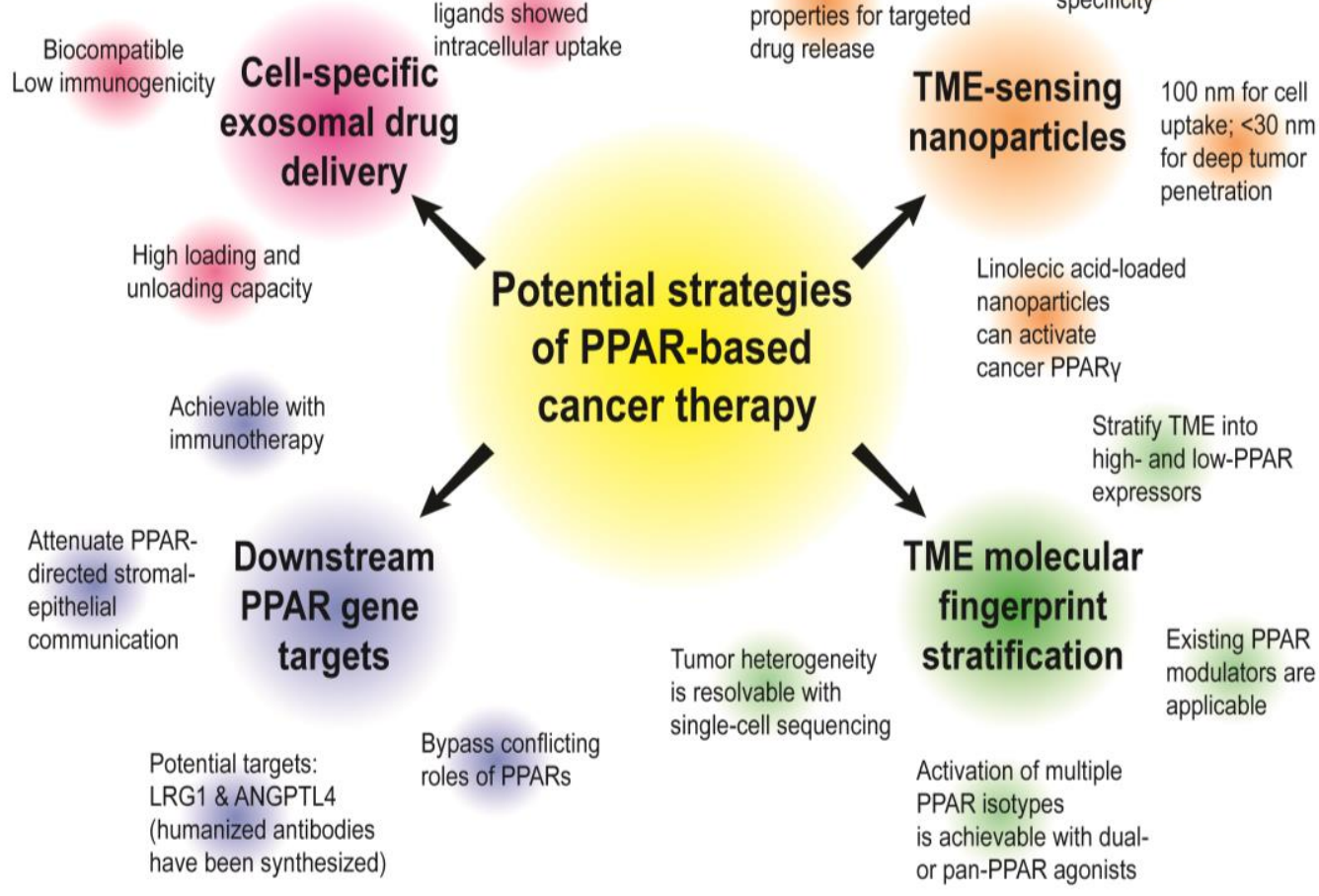

Figure 6. Possible strategies to target stromal PPARs for precision oncology. In this review, we propose four strategies to achieve PPAR-based precision oncology, including (i) cell-specific exosomes, (ii) TME-sensing nanoparticles, (iii) targeting pro-tumorigenic PPAR gene targets with immunotherapy, and (iv) stratification of PPAR-related TME molecular fingerprints. The features of each strategy are summarized in the figure.

We can further restrict stromal-epithelial crosstalk by targeting downstream paracrine signals with immunotherapy. With careful selection of the drug candidates, immunotherapy can effectively shut down critical communication conduits between cancer cells and stromal cells. We have previously examined the feasibility of a nuclear receptor-based partitional strategy by targeting CAFs of skin squamous carcinoma [62]. The treatment disrupted stromal-epithelial communication, reduced xenograft tumor growth, and prevented the recurrence of chemoresistant cancer. Mounting evidence also supports the exploitation of molecular targets downstream to PPARs. In this review, we highlight LRG1 and ANGPTL4, which are key mediators of metastasis and EMT. Immunotherapy targeting these two molecules may effectively shut down PPAR-directed communication between tumor epithelium and stroma. Importantly, humanized neutralizing antibodies targeting these proteins are readily available $[154,180]$. 
Another step towards effective PPAR-mediated therapy is by stratifying cancer patients and predicting their susceptibility to PPAR drugs based on tumor genetic and transcriptomic profiles. Cancer patients may be stratified into low- and high-expressors of a specific PPAR isotype either in the stromal cells or cancer cells. New generation dual PPARs agonists may be administered to maximize their anticancer effect on the stromal and cancer cells. The heterogeneity of tumors is a technical challenge, which can be addressed using single-cell sequencing. Identifying molecular fingerprints between stromal and tumor cells in the actual TME will also be critical for a highly precise stratification strategy that enables existing PPAR-targeting drugs to be put to clinical use immediately. Additionally, the emergence of next-generation PPAR modulators [6], such as the selective PPAR $\alpha$ modulator, pemafibrate, and dual- and pan-PPAR agonists such as saroglitazar, elafibranor, lanifibranor, and chiglitazar, brings about new prospects to PPAR cancer research. We anticipate that the investigation of newer PPAR modulators and their anticancer effect in the TME will gain momentum in the years to come.

\section{Conclusions}

Despite the impacts of PPAR activities on different aspects of tumor stromal-epithelial communication and tumor progression, it is not possible to ascribe either an exclusive pro- or anti-tumorigenic role for different PPAR isotypes. This is due to controversies and/or PPAR dual activities on cancer types and different stromal cell types. Likewise, conventional agonists and antagonists which target PPARs systemically may be counterproductive, considering their differential role in cancer and stromal cells, as reflected by the outcome of existing clinical trials. Targeting PPARs in the TME still holds a great deal of untapped potential. However, there is an urgent need to devise highly specific and precise strategies to target the nuclear receptors in different stromal cells to accomplish precision medicine in cancer therapy.

Author Contributions: Conceptualization, H.S.C., W.W., N.S.T.; data curation, H.S.C., Y.S.Y., and E.K.Y.L.; writing — original draft preparation, H.S.C., Y.S.Y. and E.K.Y.L.; writing—review and editing, all authors; supervision, W.W., N.S.T. All authors have read and agreed to the published version of the manuscript.

Funding: This research received no external funding.

Acknowledgments: We would like to thank William Tan Wei Ren for his kind suggestions on the first draft and illustrations of the manuscript.

Conflicts of Interest: The authors declare no conflict of interest.

\section{References}

1. Issemann, I.; Green, S. Activation of a member of the steroid hormone receptor superfamily by peroxisome proliferators. Nature 1990, 347, 645-650. [CrossRef]

2. Dreyer, C.; Krey, G.; Keller, H.; Givel, F.; Helftenbein, G.; Wahli, W. Control of the peroxisomal beta-oxidation pathway by a novel family of nuclear hormone receptors. Cell 1992, 68, 879-887. [CrossRef]

3. Lamichane, S.; Dahal Lamichane, B.; Kwon, S.M. Pivotal Roles of Peroxisome Proliferator-Activated Receptors (PPARs) and Their Signal Cascade for Cellular and Whole-Body Energy Homeostasis. Int. J. Mol. Sci. 2018, 19, 949. [CrossRef] [PubMed]

4. Jellinger, P.S.; Handelsman, Y.; Rosenblit, P.D.; Bloomgarden, Z.T.; Fonseca, V.A.; Garber, A.J.; Grunberger, G.; Guerin, C.K.; Bell, D.S.H.; Mechanick, J.I.; et al. American Association of Clinical Endocrinologists and American College of Endocrinology Guidelines for Management of Dyslipidemia and Prevention of Cardiovascular Disease. Endocr. Pract. 2017, 23, 1-87. [CrossRef] [PubMed]

5. Davies, M.J.; D’Alessio, D.A.; Fradkin, J.; Kernan, W.N.; Mathieu, C.; Mingrone, G.; Rossing, P.; Tsapas, A.; Wexler, D.J.; Buse, J.B. Management of Hyperglycemia in Type 2 Diabetes, 2018. A Consensus Report by the American Diabetes Association (ADA) and the European Association for the Study of Diabetes (EASD). Diabetes Care 2018, 41, 2669-2701. [CrossRef] [PubMed]

6. Cheng, H.S.; Tan, W.R.; Low, Z.S.; Marvalim, C.; Lee, J.Y.H.; Tan, N.S. Exploration and Development of PPAR Modulators in Health and Disease: An Update of Clinical Evidence. Int. J. Mol. Sci. 2019, 20, 5055. [CrossRef]

7. Hong, F.; Xu, P.; Zhai, Y. The Opportunities and Challenges of Peroxisome Proliferator-Activated Receptors Ligands in Clinical Drug Discovery and Development. Int. J. Mol. Sci. 2018, 19, 2189. [CrossRef] [PubMed] 
8. Hopkins, B.D.; Goncalves, M.D.; Cantley, L.C. Obesity and Cancer Mechanisms: Cancer Metabolism. J. Clin. Oncol. 2016, 34, 4277-4283. [CrossRef]

9. Johnson, J.A.; Carstensen, B.; Witte, D.; Bowker, S.L.; Lipscombe, L.; Renehan, A.G.; Diabetes; Cancer Research, C. Diabetes and cancer (1): Evaluating the temporal relationship between type 2 diabetes and cancer incidence. Diabetologia 2012, 55, 1607-1618. [CrossRef] [PubMed]

10. Gou, Q.; Gong, X.; Jin, J.; Shi, J.; Hou, Y. Peroxisome proliferator-activated receptors (PPARs) are potential drug targets for cancer therapy. Oncotarget 2017, 8, 60704-60709. [CrossRef] [PubMed]

11. Balkwill, F.R.; Capasso, M.; Hagemann, T. The tumor microenvironment at a glance. J. Cell Sci. 2012, 125, 5591-5596. [CrossRef] [PubMed]

12. Wang, M.; Zhao, J.; Zhang, L.; Wei, F.; Lian, Y.; Wu, Y.; Gong, Z.; Zhang, S.; Zhou, J.; Cao, K.; et al. Role of tumor microenvironment in tumorigenesis. J. Cancer 2017, 8, 761-773. [CrossRef]

13. Shah, Y.M.; Morimura, K.; Yang, Q.; Tanabe, T.; Takagi, M.; Gonzalez, F.J. Peroxisome proliferator-activated receptor alpha regulates a microRNA-mediated signaling cascade responsible for hepatocellular proliferation. Mol. Cell. Biol. 2007, 27, 4238-4247. [CrossRef]

14. Cheung, C.; Akiyama, T.E.; Ward, J.M.; Nicol, C.J.; Feigenbaum, L.; Vinson, C.; Gonzalez, F.J. Diminished hepatocellular proliferation in mice humanized for the nuclear receptor peroxisome proliferator-activated receptor alpha. Cancer Res. 2004, 64, 3849-3854. [CrossRef]

15. Yaghoubizadeh, M.; Pishkar, L.; Basati, G. Aberrant Expression of Peroxisome Proliferator-Activated Receptors in Colorectal Cancer and Their Association with Cancer Progression and Prognosis. Gastrointest. Tumors 2020, 7, 11-20. [CrossRef]

16. Castelli, V.; Catanesi, M.; Alfonsetti, M.; Laezza, C.; Lombardi, F.; Cinque, B.; Cifone, M.G.; Ippoliti, R.; Benedetti, E.; Cimini, A.; et al. PPARalpha-Selective Antagonist GW6471 Inhibits Cell Growth in Breast Cancer Stem Cells Inducing Energy Imbalance and Metabolic Stress. Biomedicines 2021, 9, 127. [CrossRef]

17. Papi, A.; Guarnieri, T.; Storci, G.; Santini, D.; Ceccarelli, C.; Taffurelli, M.; De Carolis, S.; Avenia, N.; Sanguinetti, A.; Sidoni, A.; et al. Nuclear receptors agonists exert opposing effects on the inflammation dependent survival of breast cancer stem cells. Cell Death Differ. 2012, 19, 1208-1219. [CrossRef]

18. Kuramoto, K.; Yamamoto, M.; Suzuki, S.; Togashi, K.; Sanomachi, T.; Kitanaka, C.; Okada, M. Inhibition of the Lipid DropletPeroxisome Proliferator-Activated Receptor alpha Axis Suppresses Cancer Stem Cell Properties. Genes 2021, 12, 99. [CrossRef]

19. Bonovas, S.; Nikolopoulos, G.K.; Bagos, P.G. Use of fibrates and cancer risk: A systematic review and meta-analysis of 17 long-term randomized placebo-controlled trials. PLoS ONE 2012, 7, e45259. [CrossRef] [PubMed]

20. Grabacka, M.; Reiss, K. Anticancer Properties of PPARalpha-Effects on Cellular Metabolism and Inflammation. PPAR Res 2008, 2008, 930705. [CrossRef] [PubMed]

21. Peters, J.M.; Shah, Y.M.; Gonzalez, F.J. The role of peroxisome proliferator-activated receptors in carcinogenesis and chemoprevention. Nat. Rev. Cancer 2012, 12, 181-195. [CrossRef]

22. Augimeri, G.; Gelsomino, L.; Plastina, P.; Giordano, C.; Barone, I.; Catalano, S.; Ando, S.; Bonofiglio, D. Natural and Synthetic PPARgamma Ligands in Tumor Microenvironment: A New Potential Strategy against Breast Cancer. Int. J. Mol. Sci. 2020, 21, 9721. [CrossRef]

23. Sarraf, P.; Mueller, E.; Jones, D.; King, F.J.; DeAngelo, D.J.; Partridge, J.B.; Holden, S.A.; Chen, L.B.; Singer, S.; Fletcher, C.; et al. Differentiation and reversal of malignant changes in colon cancer through PPARgamma. Nat. Med. 1998, 4, 1046-1052. [CrossRef] [PubMed]

24. Basu-Roy, U.; Han, E.; Rattanakorn, K.; Gadi, A.; Verma, N.; Maurizi, G.; Gunaratne, P.H.; Coarfa, C.; Kennedy, O.D.; Garabedian, M.J.; et al. PPARgamma agonists promote differentiation of cancer stem cells by restraining YAP transcriptional activity. Oncotarget 2016, 7, 60954-60970. [CrossRef] [PubMed]

25. Mueller, E.; Sarraf, P.; Tontonoz, P.; Evans, R.M.; Martin, K.J.; Zhang, M.; Fletcher, C.; Singer, S.; Spiegelman, B.M. Terminal differentiation of human breast cancer through PPAR gamma. Mol. Cell 1998, 1, 465-470. [CrossRef]

26. Wang, Y.; Tan, H.; Xu, D.; Ma, A.; Zhang, L.; Sun, J.; Yang, Z.; Liu, Y.; Shi, G. The combinatory effects of PPAR-gamma agonist and survivin inhibition on the cancer stem-like phenotype and cell proliferation in bladder cancer cells. Int. J. Mol. Med. 2014, 34, 262-268. [CrossRef] [PubMed]

27. Kramer, K.; Wu, J.; Crowe, D.L. Tumor suppressor control of the cancer stem cell niche. Oncogene 2016, 35, 4165-4178. [CrossRef]

28. Liu, L.; Yang, Z.; Xu, Y.; Li, J.; Xu, D.; Zhang, L.; Sun, J.; Xia, S.; Zou, F.; Liu, Y. Inhibition of oxidative stress-elicited AKT activation facilitates PPARgamma agonist-mediated inhibition of stem cell character and tumor growth of liver cancer cells. PLoS ONE 2013, 8, e73038.

29. Bigoni-Ordonez, G.D.; Ortiz-Sanchez, E.; Rosendo-Chalma, P.; Valencia-Gonzalez, H.A.; Aceves, C.; Garcia-Carranca, A. Molecular iodine inhibits the expression of stemness markers on cancer stem-like cells of established cell lines derived from cervical cancer. BMC Cancer 2018, 18, 928. [CrossRef]

30. Pestereva, E.; Kanakasabai, S.; Bright, J.J. PPARgamma agonists regulate the expression of stemness and differentiation genes in brain tumour stem cells. Br. J. Cancer 2012, 106, 1702-1712. [CrossRef]

31. Shen, B.; Chu, E.S.; Zhao, G.; Man, K.; Wu, C.W.; Cheng, J.T.; Li, G.; Nie, Y.; Lo, C.M.; Teoh, N.; et al. PPARgamma inhibits hepatocellular carcinoma metastases in vitro and in mice. Br. J. Cancer 2012, 106, 1486-1494. [CrossRef] 
32. Reka, A.K.; Kurapati, H.; Narala, V.R.; Bommer, G.; Chen, J.; Standiford, T.J.; Keshamouni, V.G. Peroxisome proliferator-activated receptor-gamma activation inhibits tumor metastasis by antagonizing Smad3-mediated epithelial-mesenchymal transition. Mol. Cancer Ther. 2010, 9, 3221-3232. [CrossRef]

33. Yang, K.; Fan, K.H.; Lamprecht, S.A.; Edelmann, W.; Kopelovich, L.; Kucherlapati, R.; Lipkin, M. Peroxisome proliferator-activated receptor gamma agonist troglitazone induces colon tumors in normal C57BL/6J mice and enhances colonic carcinogenesis in Apc1638 N/+ Mlh1+/- double mutant mice. Int. J. Cancer 2005, 116, 495-499. [CrossRef] [PubMed]

34. Pino, M.V.; Kelley, M.F.; Jayyosi, Z. Promotion of colon tumors in C57BL/6J-APC(min)/+ mice by thiazolidinedione PPARgamma agonists and a structurally unrelated PPARgamma agonist. Toxicol. Pathol. 2004, 32, 58-63. [CrossRef] [PubMed]

35. Taub, M. Cancer drug troglitazone stimulates the growth and response of renal cells to hypoxia inducible factors. Biochem. Biophys. Res. Commun. 2016, 471, 342-347. [CrossRef] [PubMed]

36. Han, E.; Jang, S.Y.; Kim, G.; Lee, Y.H.; Choe, E.Y.; Nam, C.M.; Kang, E.S. Rosiglitazone Use and the Risk of Bladder Cancer in Patients With Type 2 Diabetes. Medicine 2016, 95, e2786. [CrossRef] [PubMed]

37. Galbraith, L.C.A.; Mui, E.; Nixon, C.; Hedley, A.; Strachan, D.; MacKay, G.; Sumpton, D.; Sansom, O.J.; Leung, H.Y.; Ahmad, I. PPAR-gamma induced AKT3 expression increases levels of mitochondrial biogenesis driving prostate cancer. Oncogene 2021, 40, 2355-2366. [CrossRef] [PubMed]

38. Meylan, P.; Pich, C.; Winkler, C.; Ginster, S.; Mury, L.; Sgandurra, M.; Dreos, R.; Frederick, D.T.; Hammond, M.; Boland, G.M.; et al. Low expression of the PPARgamma-regulated gene thioredoxin-interacting protein accompanies human melanoma progression and promotes experimental lung metastases. Sci. Rep. 2021, 11, 7847. [CrossRef]

39. Patitucci, C.; Couchy, G.; Bagattin, A.; Caneque, T.; de Reynies, A.; Scoazec, J.Y.; Rodriguez, R.; Pontoglio, M.; Zucman-Rossi, J.; Pende, M.; et al. Hepatocyte nuclear factor 1alpha suppresses steatosis-associated liver cancer by inhibiting PPARgamma transcription. J. Clin. Investig. 2017, 127, 1873-1888. [CrossRef] [PubMed]

40. Panasyuk, G.; Espeillac, C.; Chauvin, C.; Pradelli, L.A.; Horie, Y.; Suzuki, A.; Annicotte, J.S.; Fajas, L.; Foretz, M.; Verdeguer, F.; et al. PPARgamma contributes to PKM2 and HK2 expression in fatty liver. Nat. Commun. 2012, 3, 672. [CrossRef]

41. Unal, E.; Aslan, E.I.; Ozturk, T.; Kurnaz Gomleksiz, O.; Kucukhuseyin, O.; Tuzuner, M.B.; Seyhan, M.F.; Ozturk, O.; Yilmaz Aydogan, H. Peroxisome Proliferator-Activated Receptor Gamma Pro12Ala/C161T Genotypes and Risky Haplotype Altering Risk of Breast Cancer: A Turkish Case-Control Study. Biochem. Genet. 2021. [CrossRef]

42. Qu, H.; Zheng, Y.; Wang, Y.; Zhang, R.; Ruan, X.; Yang, G.; Liu, Z.; Zheng, H. Global and Regional Effects of Bladder Cancer Risk Associated with Pioglitazone Therapy in Patients with Diabetes. Sci. Rep. 2017, 7, 15804. [CrossRef]

43. Soccio, R.E.; Chen, E.R.; Lazar, M.A. Thiazolidinediones and the promise of insulin sensitization in type 2 diabetes. Cell Metab. 2014, 20, 573-591. [CrossRef] [PubMed]

44. Wagner, N.; Wagner, K.D. PPAR Beta/Delta and the Hallmarks of Cancer. Cells 2020, 9, 1133. [CrossRef] [PubMed]

45. Tan, N.S.; Vazquez-Carrera, M.; Montagner, A.; Sng, M.K.; Guillou, H.; Wahli, W. Transcriptional control of physiological and pathological processes by the nuclear receptor PPARbeta/delta. Prog. Lipid Res. 2016, 64, 98-122. [CrossRef] [PubMed]

46. Liu, Y.; Deguchi, Y.; Tian, R.; Wei, D.; Wu, L.; Chen, W.; Xu, W.; Xu, M.; Liu, F.; Gao, S.; et al. Pleiotropic Effects of PPARD Accelerate Colorectal Tumorigenesis, Progression, and Invasion. Cancer Res. 2019, 79, 954-969. [CrossRef]

47. Zuo, X.; Peng, Z.; Moussalli, M.J.; Morris, J.S.; Broaddus, R.R.; Fischer, S.M.; Shureiqi, I. Targeted genetic disruption of peroxisome proliferator-activated receptor-delta and colonic tumorigenesis. J. Natl. Cancer. Inst. 2009, 101, 762-767. [CrossRef] [PubMed]

48. Mao, F.; Xu, M.; Zuo, X.; Yu, J.; Xu, W.; Moussalli, M.J.; Elias, E.; Li, H.S.; Watowich, S.S.; Shureiqi, I. 15-Lipoxygenase-1 suppression of colitis-associated colon cancer through inhibition of the IL-6/STAT3 signaling pathway. FASEB J. 2015, 29, 2359-2370. [CrossRef]

49. Beyaz, S.; Mana, M.D.; Roper, J.; Kedrin, D.; Saadatpour, A.; Hong, S.J.; Bauer-Rowe, K.E.; Xifaras, M.E.; Akkad, A.; Arias, E.; et al. High-fat diet enhances stemness and tumorigenicity of intestinal progenitors. Nature 2016, 531, 53-58. [CrossRef] [PubMed]

50. Zuo, X.; Xu, W.; Xu, M.; Tian, R.; Moussalli, M.J.; Mao, F.; Zheng, X.; Wang, J.; Morris, J.S.; Gagea, M.; et al. Metastasis regulation by PPARD expression in cancer cells. JCI Insight 2017, 2, e91419. [CrossRef] [PubMed]

51. Pollock, C.B.; Yin, Y.; Yuan, H.; Zeng, X.; King, S.; Li, X.; Kopelovich, L.; Albanese, C.; Glazer, R.I. PPARdelta activation acts cooperatively with 3-phosphoinositide-dependent protein kinase-1 to enhance mammary tumorigenesis. PLoS ONE 2011, 6, e16215. [CrossRef]

52. Montagner, A.; Delgado, M.B.; Tallichet-Blanc, C.; Chan, J.S.; Sng, M.K.; Mottaz, H.; Degueurce, G.; Lippi, Y.; Moret, C.; Baruchet, M.; et al. Src is activated by the nuclear receptor peroxisome proliferator-activated receptor beta/delta in ultraviolet radiation-induced skin cancer. EMBO Mol. Med. 2014, 6, 80-98. [CrossRef] [PubMed]

53. Her, N.G.; Jeong, S.I.; Cho, K.; Ha, T.K.; Han, J.; Ko, K.P.; Park, S.K.; Lee, J.H.; Lee, M.G.; Ryu, B.K.; et al. PPARdelta promotes oncogenic redirection of TGF-beta1 signaling through the activation of the ABCA1-Cav1 pathway. Cell Cycle 2013, 12, 1521-1535. [CrossRef]

54. Wang, D.; Fu, L.; Wei, J.; Xiong, Y.; DuBois, R.N. PPARdelta Mediates the Effect of Dietary Fat in Promoting Colorectal Cancer Metastasis. Cancer Res. 2019, 79, 4480-4490. [CrossRef]

55. Yao, P.L.; Chen, L.; Dobrzanski, T.P.; Zhu, B.; Kang, B.H.; Muller, R.; Gonzalez, F.J.; Peters, J.M. Peroxisome proliferator-activated receptor-beta/delta inhibits human neuroblastoma cell tumorigenesis by inducing p53- and SOX2-mediated cell differentiation. Mol. Carcinog. 2017, 56, 1472-1483. [CrossRef] [PubMed] 
56. Harman, F.S.; Nicol, C.J.; Marin, H.E.; Ward, J.M.; Gonzalez, F.J.; Peters, J.M. Peroxisome proliferator-activated receptor-delta attenuates colon carcinogenesis. Nat. Med. 2004, 10, 481-483. [CrossRef] [PubMed]

57. Yang, L.; Zhou, J.; Ma, Q.; Wang, C.; Chen, K.; Meng, W.; Yu, Y.; Zhou, Z.; Sun, X. Knockdown of PPAR delta gene promotes the growth of colon cancer and reduces the sensitivity to bevacizumab in nude mice model. PLoS ONE 2013, 8, e60715.

58. Foreman, J.E.; Chang, W.C.; Palkar, P.S.; Zhu, B.; Borland, M.G.; Williams, J.L.; Kramer, L.R.; Clapper, M.L.; Gonzalez, F.J.; Peters, J.M. Functional characterization of peroxisome proliferator-activated receptor-beta/delta expression in colon cancer. Mol. Carcinog. 2011, 50, 884-900. [CrossRef] [PubMed]

59. Alam, M.M.; Lal, S.; FitzGerald, K.E.; Zhang, L. A holistic view of cancer bioenergetics: Mitochondrial function and respiration play fundamental roles in the development and progression of diverse tumors. Clin. Transl. Med. 2016, 5, 3. [CrossRef] [PubMed]

60. Martinez-Outschoorn, U.E.; Lisanti, M.P.; Sotgia, F. Catabolic cancer-associated fibroblasts transfer energy and biomass to anabolic cancer cells, fueling tumor growth. Semin. Cancer Biol. 2014, 25, 47-60. [CrossRef]

61. Vandoros, G.P.; Konstantinopoulos, P.A.; Sotiropoulou-Bonikou, G.; Kominea, A.; Papachristou, G.I.; Karamouzis, M.V.; Gkermpesi, M.; Varakis, I.; Papavassiliou, A.G. PPAR-gamma is expressed and NF- $\mathrm{kB}$ pathway is activated and correlates positively with COX-2 expression in stromal myofibroblasts surrounding colon adenocarcinomas. J. Cancer Res. Clin. Oncol. 2006, 132, 76-84. [CrossRef]

62. Chan, J.S.K.; Sng, M.K.; Teo, Z.Q.; Chong, H.C.; Twang, J.S.; Tan, N.S. Targeting nuclear receptors in cancer-associated fibroblasts as concurrent therapy to inhibit development of chemoresistant tumors. Oncogene 2018, 37, 160-173. [CrossRef]

63. Avena, P.; Anselmo, W.; Whitaker-Menezes, D.; Wang, C.; Pestell, R.G.; Lamb, R.S.; Hulit, J.; Casaburi, I.; Ando, S.; MartinezOutschoorn, U.E.; et al. Compartment-specific activation of PPARgamma governs breast cancer tumor growth, via metabolic reprogramming and symbiosis. Cell Cycle 2013, 12, 1360-1370. [CrossRef] [PubMed]

64. Pavlides, S.; Vera, I.; Gandara, R.; Sneddon, S.; Pestell, R.G.; Mercier, I.; Martinez-Outschoorn, U.E.; Whitaker-Menezes, D.; Howell, A.; Sotgia, F.; et al. Warburg meets autophagy: Cancer-associated fibroblasts accelerate tumor growth and metastasis via oxidative stress, mitophagy, and aerobic glycolysis. Antioxid. Redox Signal. 2012, 16, 1264-1284. [CrossRef]

65. Boutoual, R.; Meseguer, S.; Villarroya, M.; Martin-Hernandez, E.; Errami, M.; Martin, M.A.; Casado, M.; Armengod, M.E. Defects in the mitochondrial-tRNA modification enzymes MTO1 and GTPBP3 promote different metabolic reprogramming through a HIF-PPARgamma-UCP2-AMPK axis. Sci. Rep. 2018, 8, 1163. [CrossRef] [PubMed]

66. Jang, M.; Park, R.; Kim, H.; Namkoong, S.; Jo, D.; Huh, Y.H.; Jang, I.S.; Lee, J.I.; Park, J. AMPK contributes to autophagosome maturation and lysosomal fusion. Sci. Rep. 2018, 8, 12637. [CrossRef]

67. Wang, S.; Kandadi, M.R.; Ren, J. Double knockout of Akt2 and AMPK predisposes cardiac aging without affecting lifespan: Role of autophagy and mitophagy. Biochim. Biophys. Acta. Mol. Basis Dis. 2019, 1865, 1865-1875. [CrossRef] [PubMed]

68. Jiao, L.; Zhang, H.L.; Li, D.D.; Yang, K.L.; Tang, J.; Li, X.; Ji, J.; Yu, Y.; Wu, R.Y.; Ravichandran, S.; et al. Regulation of glycolytic metabolism by autophagy in liver cancer involves selective autophagic degradation of HK2 (hexokinase 2). Autophagy 2018, 14, 671-684. [CrossRef] [PubMed]

69. Fan, Q.; Yang, L.; Zhang, X.; Ma, Y.; Li, Y.; Dong, L.; Zong, Z.; Hua, X.; Su, D.; Li, H.; et al. Autophagy promotes metastasis and glycolysis by upregulating MCT1 expression and Wnt/beta-catenin signaling pathway activation in hepatocellular carcinoma cells. J. Exp. Clin. Cancer Res. 2018, 37, 9. [CrossRef]

70. Shashni, B.; Sakharkar, K.R.; Nagasaki, Y.; Sakharkar, M.K. Glycolytic enzymes PGK1 and PKM2 as novel transcriptional targets of PPARgamma in breast cancer pathophysiology. J. Drug Target. 2013, 21, 161-174. [CrossRef]

71. Zhang, H.; Li, L.; Chen, Q.; Li, M.; Feng, J.; Sun, Y.; Zhao, R.; Zhu, Y.; Lv, Y.; Zhu, Z.; et al. PGC1beta regulates multiple myeloma tumor growth through LDHA-mediated glycolytic metabolism. Mol. Oncol. 2018, 12, 1579-1595. [CrossRef] [PubMed]

72. Londhe, P.; Yu, P.Y.; Ijiri, Y.; Ladner, K.J.; Fenger, J.M.; London, C.; Houghton, P.J.; Guttridge, D.C. Classical NF-kappaB Metabolically Reprograms Sarcoma Cells Through Regulation of Hexokinase 2. Front. Oncol. 2018, 8, 104. [CrossRef]

73. Wu, Q.; Li, B.; Li, Z.; Li, J.; Sun, S.; Sun, S. Cancer-associated adipocytes: Key players in breast cancer progression. J. Hematol. Oncol. 2019, 12, 95. [CrossRef] [PubMed]

74. Wolins, N.E.; Quaynor, B.K.; Skinner, J.R.; Tzekov, A.; Park, C.; Choi, K.; Bickel, P.E. OP9 mouse stromal cells rapidly differentiate into adipocytes: Characterization of a useful new model of adipogenesis. J. Lipid Res. 2006, 47, 450-460. [CrossRef]

75. Chen, J.H.; Goh, K.J.; Rocha, N.; Groeneveld, M.P.; Minic, M.; Barrett, T.G.; Savage, D.; Semple, R.K. Evaluation of human dermal fibroblasts directly reprogrammed to adipocyte-like cells as a metabolic disease model. Dis. Model. Mech. 2017, 10, 1411-1420. [CrossRef] [PubMed]

76. Wu, Q.; Li, J.; Li, Z.; Sun, S.; Zhu, S.; Wang, L.; Wu, J.; Yuan, J.; Zhang, Y.; Sun, S.; et al. Exosomes from the tumour-adipocyte interplay stimulate beige/brown differentiation and reprogram metabolism in stromal adipocytes to promote tumour progression. J. Exp. Clin. Cancer Res. 2019, 38, 223. [CrossRef] [PubMed]

77. Wu, Q.; Sun, S.; Li, Z.; Yang, Q.; Li, B.; Zhu, S.; Wang, L.; Wu, J.; Yuan, J.; Yang, C.; et al. Tumour-originated exosomal miR-155 triggers cancer-associated cachexia to promote tumour progression. Mol. Cancer 2018, 17, 155. [CrossRef]

78. Cai, Z.; Liang, Y.; Xing, C.; Wang, H.; Hu, P.; Li, J.; Huang, H.; Wang, W.; Jiang, C. Cancer associated adipocytes exhibit distinct phenotypes and facilitate tumor progression in pancreatic cancer. Oncol. Rep. 2019, 42, 2537-2549. [CrossRef] [PubMed]

79. Zoico, E.; Darra, E.; Rizzatti, V.; Budui, S.; Franceschetti, G.; Mazzali, G.; Rossi, A.P.; Fantin, F.; Menegazzi, M.; Cinti, S.; et al. Adipocytes WNT5a mediated dedifferentiation: A possible target in pancreatic cancer microenvironment. Oncotarget 2016, 7, 20223-20235. [CrossRef] 
80. Bi, P.; Yue, F.; Karki, A.; Castro, B.; Wirbisky, S.E.; Wang, C.; Durkes, A.; Elzey, B.D.; Andrisani, O.M.; Bidwell, C.A.; et al. Notch activation drives adipocyte dedifferentiation and tumorigenic transformation in mice. J. Exp. Med. 2016, 213, $2019-2037$. [CrossRef] [PubMed]

81. Skelhorne-Gross, G.; Reid, A.L.; Apostoli, A.J.; Di Lena, M.A.; Rubino, R.E.; Peterson, N.T.; Schneider, M.; SenGupta, S.K.; Gonzalez, F.J.; Nicol, C.J. Stromal adipocyte PPARgamma protects against breast tumorigenesis. Carcinogenesis 2012, 33, 1412-1420. [CrossRef] [PubMed]

82. Matsumoto, T.; Kano, K.; Kondo, D.; Fukuda, N.; Iribe, Y.; Tanaka, N.; Matsubara, Y.; Sakuma, T.; Satomi, A.; Otaki, M.; et al. Mature adipocyte-derived dedifferentiated fat cells exhibit multilineage potential. J. Cell Physiol. 2008, 215, 210-222. [CrossRef] [PubMed]

83. Pereira, B.A.; Vennin, C.; Papanicolaou, M.; Chambers, C.R.; Herrmann, D.; Morton, J.P.; Cox, T.R.; Timpson, P. CAF Subpopulations: A New Reservoir of Stromal Targets in Pancreatic Cancer. Trends Cancer 2019, 5, 724-741. [CrossRef]

84. Yoshida, G.J.; Azuma, A.; Miura, Y.; Orimo, A. Activated Fibroblast Program Orchestrates Tumor Initiation and Progression; Molecular Mechanisms and the Associated Therapeutic Strategies. Int. J. Mol. Sci. 2019, 20, 2256. [CrossRef] [PubMed]

85. Tan, M.W.Y.; Sng, M.K.; Cheng, H.S.; Low, Z.S.; Leong, B.J.J.; Chua, D.; Tan, E.H.P.; Chan, J.S.K.; Yip, Y.S.; Lee, Y.H.; et al. Deficiency in fibroblast PPARbeta/delta reduces nonmelanoma skin cancers in mice. Cell Death Differ. 2020. [CrossRef]

86. Tan, E.H.P.; Sng, M.K.; How, I.S.B.; Chan, J.S.K.; Chen, J.; Tan, C.K.; Wahli, W.; Tan, N.S. ROS release by PPARbeta/delta-null fibroblasts reduces tumor load through epithelial antioxidant response. Oncogene 2018, 37, 2067-2078. [CrossRef]

87. Sng, M.K.; Chan, J.S.K.; Teo, Z.; Phua, T.; Tan, E.H.P.; Wee, J.W.K.; Koh, N.J.N.; Tan, C.K.; Chen, J.P.; Pal, M.; et al. Selective deletion of PPARbeta/delta in fibroblasts causes dermal fibrosis by attenuated LRG1 expression. Cell Discov. 2018, 4, 15. [CrossRef]

88. Zhang, Q.; Huang, R.; Tang, Q.; Yu, Y.; Huang, Q.; Chen, Y.; Wang, G.; Wang, X. Leucine-rich alpha-2-glycoprotein-1 is up-regulated in colorectal cancer and is a tumor promoter. Onco Targets Ther. 2018, 11, 2745-2752. [CrossRef]

89. Xie, Z.B.; Zhang, Y.F.; Jin, C.; Mao, Y.S.; Fu, D.L. LRG-1 promotes pancreatic cancer growth and metastasis via modulation of the EGFR/p38 signaling. J. Exp. Clin. Cancer Res. 2019, 38, 75. [CrossRef]

90. Zhou, Y.; Zhang, X.; Zhang, J.; Fang, J.; Ge, Z.; Li, X. LRG1 promotes proliferation and inhibits apoptosis in colorectal cancer cells via RUNX1 activation. PLoS ONE 2017, 12, e0175122. [CrossRef]

91. Liu, C.; Lim, S.T.; Teo, M.H.Y.; Tan, M.S.Y.; Kulkarni, M.D.; Qiu, B.; Li, A.; Lal, S.; Dos Remedios, C.G.; Tan, N.S.; et al. Collaborative Regulation of LRG1 by TGF-beta1 and PPAR-beta/delta Modulates Chronic Pressure Overload-Induced Cardiac Fibrosis. Circ. Heart Fail. 2019, 12, e005962. [CrossRef]

92. Eales, K.L.; Hollinshead, K.E.; Tennant, D.A. Hypoxia and metabolic adaptation of cancer cells. Oncogenesis 2016, 5, e190. [CrossRef]

93. Panigrahy, D.; Kaipainen, A.; Huang, S.; Butterfield, C.E.; Barnes, C.M.; Fannon, M.; Laforme, A.M.; Chaponis, D.M.; Folkman, J.; Kieran, M.W. PPARalpha agonist fenofibrate suppresses tumor growth through direct and indirect angiogenesis inhibition. Proc. Natl. Acad. Sci. USA 2008, 105, 985-990. [CrossRef] [PubMed]

94. Pozzi, A.; Ibanez, M.R.; Gatica, A.E.; Yang, S.; Wei, S.; Mei, S.; Falck, J.R.; Capdevila, J.H. Peroxisomal proliferator-activated receptor-alpha-dependent inhibition of endothelial cell proliferation and tumorigenesis. J. Biol. Chem. 2007, 282, 17685-17695. [CrossRef] [PubMed]

95. Arima, T.; Uchiyama, M.; Nakano, Y.; Nagasaka, S.; Kang, D.; Shimizu, A.; Takahashi, H. Peroxisome proliferator-activated receptor alpha agonist suppresses neovascularization by reducing both vascular endothelial growth factor and angiopoietin-2 in corneal alkali burn. Sci. Rep. 2017, 7, 17763. [CrossRef]

96. Pozzi, A.; Popescu, V.; Yang, S.; Mei, S.; Shi, M.; Puolitaival, S.M.; Caprioli, R.M.; Capdevila, J.H. The anti-tumorigenic properties of peroxisomal proliferator-activated receptor alpha are arachidonic acid epoxygenase-mediated. J. Biol. Chem. 2010, 285, 12840-12850. [CrossRef] [PubMed]

97. Leu, J.-G.; Chiang, M.-H.; Chen, C.-Y.; Lin, J.-T.; Chen, H.-M.; Chen, Y.-L.; Liang, Y.-J. Adenine accelerated the diabetic wound healing by PPAR delta and angiogenic regulation. Eur. J. Pharmacol. 2018, 818, 569-577. [CrossRef]

98. Montagner, A.; Wahli, W.; Tan, N.S. Nuclear receptor peroxisome proliferator activated receptor (PPAR) beta/delta in skin wound healing and cancer. Eur. J. Dermatol. 2015, 25 (Suppl. 1), 4-11. [PubMed]

99. Tan, N.S.; Icre, G.; Montagner, A.; Bordier-ten-Heggeler, B.; Wahli, W.; Michalik, L. The nuclear hormone receptor peroxisome proliferator-activated receptor beta/delta potentiates cell chemotactism, polarization, and migration. Mol. Cell Biol. 2007, 27, 7161-7175. [CrossRef]

100. Piqueras, L.; Reynolds, A.R.; Hodivala-Dilke, K.M.; Alfranca, A.; Redondo, J.M.; Hatae, T.; Tanabe, T.; Warner, T.D.; Bishop-Bailey, D. Activation of PPARbeta/delta induces endothelial cell proliferation and angiogenesis. Arterioscler. Thromb. Vasc. Biol. 2007, 27, 63-69. [CrossRef]

101. Wagner, K.D.; Du, S.; Martin, L.; Leccia, N.; Michiels, J.F.; Wagner, N. Vascular PPARbeta/delta Promotes Tumor Angiogenesis and Progression. Cells 2019, 8, 1623. [CrossRef]

102. Muller-Brusselbach, S.; Komhoff, M.; Rieck, M.; Meissner, W.; Kaddatz, K.; Adamkiewicz, J.; Keil, B.; Klose, K.J.; Moll, R.; Burdick, A.D.; et al. Deregulation of tumor angiogenesis and blockade of tumor growth in PPARbeta-deficient mice. EMBO J. 2007, 26, 3686-3698. [CrossRef] 
103. Abdollahi, A.; Schwager, C.; Kleeff, J.; Esposito, I.; Domhan, S.; Peschke, P.; Hauser, K.; Hahnfeldt, P.; Hlatky, L.; Debus, J.; et al. Transcriptional network governing the angiogenic switch in human pancreatic cancer. Proc. Natl. Acad. Sci. USA 2007, 104, 12890-12895. [CrossRef]

104. Meissner, M.; Hrgovic, I.; Doll, M.; Naidenow, J.; Reichenbach, G.; Hailemariam-Jahn, T.; Michailidou, D.; Gille, J.; Kaufmann, R. Peroxisome proliferator-activated receptor $\delta$ activators induce IL-8 expression in nonstimulated endothelial cells in a transcriptional and posttranscriptional manner. J. Biol. Chem. 2010, 285, 33797-33804. [CrossRef] [PubMed]

105. Adamkiewicz, J.; Kaddatz, K.; Rieck, M.; Wilke, B.; Muller-Brusselbach, S.; Muller, R. Proteomic profile of mouse fibroblasts with a targeted disruption of the peroxisome proliferator activated receptor-beta/delta gene. Proteomics 2007, 7, 1208-1216. [CrossRef]

106. Possati, L.; Rocchetti, R.; Talevi, S.; Beatrici, V.; Margiotta, C.; Ferrante, L.; Calza, R.; Sagrini, D.; Ferri, A. The role of peroxisome proliferator-activated receptor gamma in bladder cancer in relation to angiogenesis and progression. Gen. Pharmacol. 2000, 35, 269-275. [CrossRef]

107. Huang, W.; Shao, M.; Liu, H.; Chen, J.; Hu, J.; Zhu, L.; Liu, F.; Wang, D.; Zou, Y.; Xiong, Y.; et al. Fibroblast growth factor 21 enhances angiogenesis and wound healing of human brain microvascular endothelial cells by activating PPARgamma. J. Pharmacol. Sci. 2019, 140, 120-127. [CrossRef]

108. Xin, X.; Yang, S.; Kowalski, J.; Gerritsen, M.E. Peroxisome proliferator-activated receptor gamma ligands are potent inhibitors of angiogenesis in vitro and in vivo. J. Biol. Chem. 1999, 274, 9116-9121. [CrossRef] [PubMed]

109. Sarayba, M.A.; Li, L.; Tungsiripat, T.; Liu, N.H.; Sweet, P.M.; Patel, A.J.; Osann, K.E.; Chittiboyina, A.; Benson, S.C.; Pershadsingh, H.A.; et al. Inhibition of corneal neovascularization by a peroxisome proliferator-activated receptor-gamma ligand. Exp. Eye Res. 2005, 80, 435-442. [CrossRef] [PubMed]

110. Biscetti, F.; Gaetani, E.; Flex, A.; Aprahamian, T.; Hopkins, T.; Straface, G.; Pecorini, G.; Stigliano, E.; Smith, R.C.; Angelini, F.; et al. Selective activation of peroxisome proliferator-activated receptor (PPAR)alpha and PPAR gamma induces neoangiogenesis through a vascular endothelial growth factor-dependent mechanism. Diabetes 2008, 57, 1394-1404. [CrossRef] [PubMed]

111. Vattulainen-Collanus, S.; Akinrinade, O.; Li, M.; Koskenvuo, M.; Li, C.G.; Rao, S.P.; de Jesus Perez, V.; Yuan, K.; Sawada, H.; Koskenvuo, J.W.; et al. Loss of PPARgamma in endothelial cells leads to impaired angiogenesis. J. Cell Sci. 2016, 129, 693-705. [CrossRef]

112. Bishop-Bailey, D.; Swales, K.E. The Role of PPARs in the Endothelium: Implications for Cancer Therapy. PPAR Res. 2008, 2008, 904251. [CrossRef]

113. Kusuma, G.D.; Carthew, J.; Lim, R.; Frith, J.E. Effect of the Microenvironment on Mesenchymal Stem Cell Paracrine Signaling: Opportunities to Engineer the Therapeutic Effect. Stem. Cells Dev. 2017, 26, 617-631. [CrossRef]

114. Kim, T.W.; Hong, D.W.; Hong, S.H. CB13, a novel PPARgamma ligand, overcomes radio-resistance via ROS generation and ER stress in human non-small cell lung cancer. Cell Death Dis. 2020, 11, 848. [CrossRef]

115. Rigas, B.; Goldman, I.S.; Levine, L. Altered eicosanoid levels in human colon cancer. J. Lab. Clin. Med. 1993, 122, 518-523.

116. Paulitschke, V.; Gruber, S.; Hofstatter, E.; Haudek-Prinz, V.; Klepeisz, P.; Schicher, N.; Jonak, C.; Petzelbauer, P.; Pehamberger, H.; Gerner, C.; et al. Proteome analysis identified the PPARgamma ligand 15d-PGJ2 as a novel drug inhibiting melanoma progression and interfering with tumor-stroma interaction. PLOS ONE 2012, 7, e46103. [CrossRef]

117. Rovito, D.; Gionfriddo, G.; Barone, I.; Giordano, C.; Grande, F.; De Amicis, F.; Lanzino, M.; Catalano, S.; Ando, S.; Bonofiglio, D. Ligand-activated PPARgamma downregulates CXCR4 gene expression through a novel identified PPAR response element and inhibits breast cancer progression. Oncotarget 2016, 7, 65109-65124. [CrossRef] [PubMed]

118. Papi, A.; De Carolis, S.; Bertoni, S.; Storci, G.; Sceberras, V.; Santini, D.; Ceccarelli, C.; Taffurelli, M.; Orlandi, M.; Bonafe, M. PPARgamma and RXR ligands disrupt the inflammatory cross-talk in the hypoxic breast cancer stem cells niche. J. Cell. Physiol. 2014, 229, 1595-1606. [CrossRef] [PubMed]

119. Kim, N.; Choi, S.; Lim, C.; Lee, H.; Oh, J. Albumin mediates PPAR-gamma or C/EBP-alpha-induced phenotypic changes in pancreatic stellate cells. Biochem. Biophys. Res. Commun. 2010, 391, 640-644. [CrossRef] [PubMed]

120. Sharvit, E.; Abramovitch, S.; Reif, S.; Bruck, R. Amplified inhibition of stellate cell activation pathways by PPAR-gamma, RAR and RXR agonists. PLoS ONE 2013, 8, e76541. [CrossRef]

121. Zhang, Q.; Xiang, S.; Liu, Q.; Gu, T.; Yao, Y.; Lu, X. PPARgamma Antagonizes Hypoxia-Induced Activation of Hepatic Stellate Cell through Cross Mediating PI3K/AKT and cGMP/PKG Signaling. PPAR Res. 2018, 2018, 6970407. [CrossRef] [PubMed]

122. Shimizu, K.; Kobayashi, M.; Tahara, J.; Shiratori, K. Cytokines and peroxisome proliferator-activated receptor gamma ligand regulate phagocytosis by pancreatic stellate cells. Gastroenterology 2005, 128, 2105-2118. [CrossRef]

123. Pich, C.; Meylan, P.; Mastelic-Gavillet, B.; Nguyen, T.N.; Loyon, R.; Trang, B.K.; Moser, H.; Moret, C.; Goepfert, C.; Hafner, J.; et al. Induction of Paracrine Signaling in Metastatic Melanoma Cells by PPARgamma Agonist Rosiglitazone Activates Stromal Cells and Enhances Tumor Growth. Cancer Res. 2018, 78, 6447-6461. [CrossRef]

124. Christofides, A.; Konstantinidou, E.; Jani, C.; Boussiotis, V.A. The role of peroxisome proliferator-activated receptors (PPAR) in immune responses. Metabolism 2021, 114, 154338. [CrossRef] [PubMed]

125. Gionfriddo, G.; Plastina, P.; Augimeri, G.; Catalano, S.; Giordano, C.; Barone, I.; Morelli, C.; Giordano, F.; Gelsomino, L.; Sisci, D.; et al. Modulating Tumor-Associated Macrophage Polarization by Synthetic and Natural PPARgamma Ligands as a Potential Target in Breast Cancer. Cells 2020, 9, 174. [CrossRef] 
126. Penas, F.; Mirkin, G.A.; Vera, M.; Cevey, A.; Gonzalez, C.D.; Gomez, M.I.; Sales, M.E.; Goren, N.B. Treatment in vitro with PPARalpha and PPARgamma ligands drives M1-to-M2 polarization of macrophages from T. cruzi-infected mice. Biochim. Biophys. Acta 2015, 1852, 893-904. [CrossRef] [PubMed]

127. Odegaard, J.I.; Ricardo-Gonzalez, R.R.; Goforth, M.H.; Morel, C.R.; Subramanian, V.; Mukundan, L.; Red Eagle, A.; Vats, D.; Brombacher, F.; Ferrante, A.W.; et al. Macrophage-specific PPARgamma controls alternative activation and improves insulin resistance. Nature 2007, 447, 1116-1120. [CrossRef] [PubMed]

128. Vats, D.; Mukundan, L.; Odegaard, J.I.; Zhang, L.; Smith, K.L.; Morel, C.R.; Wagner, R.A.; Greaves, D.R.; Murray, P.J.; Chawla, A. Oxidative metabolism and PGC-1beta attenuate macrophage-mediated inflammation. Cell Metab. 2006, 4, 13-24. [CrossRef]

129. Souza-Moreira, L.; Soares, V.C.; Dias, S.; Bozza, P.T. Adipose-derived Mesenchymal Stromal Cells Modulate Lipid Metabolism and Lipid Droplet Biogenesis via AKT/mTOR -PPARgamma Signalling in Macrophages. Sci. Rep. 2019, 9, 20304. [CrossRef]

130. Niu, Z.; Shi, Q.; Zhang, W.; Shu, Y.; Yang, N.; Chen, B.; Wang, Q.; Zhao, X.; Chen, J.; Cheng, N.; et al. Caspase-1 cleaves PPARgamma for potentiating the pro-tumor action of TAMs. Nat. Commun. 2017, 8, 766. [CrossRef] [PubMed]

131. Zhao, F.; Xiao, C.; Evans, K.S.; Theivanthiran, T.; DeVito, N.; Holtzhausen, A.; Liu, J.; Liu, X.; Boczkowski, D.; Nair, S.; et al Paracrine Wnt5a-beta-Catenin Signaling Triggers a Metabolic Program that Drives Dendritic Cell Tolerization. Immunity 2018, 48, 147-160 e147. [CrossRef]

132. Schumann, T.; Adhikary, T.; Wortmann, A.; Finkernagel, F.; Lieber, S.; Schnitzer, E.; Legrand, N.; Schober, Y.; Nockher, W.A.; Toth, P.M.; et al. Deregulation of PPARbeta/delta target genes in tumor-associated macrophages by fatty acid ligands in the ovarian cancer microenvironment. Oncotarget 2015, 6, 13416-13433. [CrossRef]

133. Odegaard, J.I.; Ricardo-Gonzalez, R.R.; Red Eagle, A.; Vats, D.; Morel, C.R.; Goforth, M.H.; Subramanian, V.; Mukundan, L.; Ferrante, A.W.; Chawla, A. Alternative M2 activation of Kupffer cells by PPARdelta ameliorates obesity-induced insulin resistance. Cell Metab. 2008, 7, 496-507. [CrossRef] [PubMed]

134. Cheng, W.Y.; Huynh, H.; Chen, P.; Pena-Llopis, S.; Wan, Y. Macrophage PPARgamma inhibits Gpr132 to mediate the anti-tumor effects of rosiglitazone. Elife 2016, 5, e18502. [CrossRef]

135. Van Ginderachter, J.A.; Meerschaut, S.; Liu, Y.; Brys, L.; De Groeve, K.; Hassanzadeh Ghassabeh, G.; Raes, G.; De Baetselier, P. Peroxisome proliferator-activated receptor gamma (PPARgamma) ligands reverse CTL suppression by alternatively activated (M2) macrophages in cancer. Blood 2006, 108, 525-535. [CrossRef] [PubMed]

136. Kim, Y.B.; Ahn, Y.H.; Jung, J.H.; Lee, Y.J.; Lee, J.H.; Kang, J.L. Programming of macrophages by UV-irradiated apoptotic cancer cells inhibits cancer progression and lung metastasis. Cell. Mol. Immunol. 2019, 16, 851-867. [CrossRef]

137. Yin, X.; Zeng, W.; Wu, B.; Wang, L.; Wang, Z.; Tian, H.; Wang, L.; Jiang, Y.; Clay, R.; Wei, X.; et al. PPARalpha Inhibition Overcomes Tumor-Derived Exosomal Lipid-Induced Dendritic Cell Dysfunction. Cell Rep. 2020, 33, 108278. [CrossRef]

138. Tan, M.J.; Teo, Z.; Sng, M.K.; Zhu, P.; Tan, N.S. Emerging roles of angiopoietin-like 4 in human cancer. Mol. Cancer Res. 2012, 10, 677-688. [CrossRef] [PubMed]

139. Zhu, P.; Goh, Y.Y.; Chin, H.F.; Kersten, S.; Tan, N.S. Angiopoietin-like 4: A decade of research. Biosci. Rep. 2012, 32, 211-219. [CrossRef]

140. Kim, S.H.; Park, Y.Y.; Kim, S.W.; Lee, J.S.; Wang, D.; DuBois, R.N. ANGPTL4 induction by prostaglandin E2 under hypoxic conditions promotes colorectal cancer progression. Cancer Res. 2011, 71, 7010-7020. [CrossRef] [PubMed]

141. Kersten, S.; Mandard, S.; Tan, N.S.; Escher, P.; Metzger, D.; Chambon, P.; Gonzalez, F.J.; Desvergne, B.; Wahli, W. Characterization of the fasting-induced adipose factor FIAF, a novel peroxisome proliferator-activated receptor target gene. J. Biol. Chem. 2000, 275, 28488-28493. [CrossRef] [PubMed]

142. Ge, H.; Yang, G.; Huang, L.; Motola, D.L.; Pourbahrami, T.; Li, C. Oligomerization and regulated proteolytic processing of angiopoietin-like protein 4. J. Biol. Chem. 2004, 279, 2038-2045. [CrossRef] [PubMed]

143. La Paglia, L.; Listi, A.; Caruso, S.; Amodeo, V.; Passiglia, F.; Bazan, V.; Fanale, D. Potential Role of ANGPTL4 in the Cross Talk between Metabolism and Cancer through PPAR Signaling Pathway. PPAR Res. 2017, 2017, 8187235. [CrossRef]

144. Zhou, S.; Wang, R.; Xiao, H. Adipocytes induce the resistance of ovarian cancer to carboplatin through ANGPTL4. Oncol. Rep. 2020, 44, 927-938. [CrossRef] [PubMed]

145. Cai, Y.C.; Yang, H.; Wang, K.F.; Chen, T.H.; Jiang, W.Q.; Shi, Y.X. ANGPTL4 overexpression inhibits tumor cell adhesion and migration and predicts favorable prognosis of triple-negative breast cancer. BMC Cancer 2020, 20, 878. [CrossRef]

146. Hsieh, H.Y.; Jou, Y.C.; Tung, C.L.; Tsai, Y.S.; Wang, Y.H.; Chi, C.L.; Lin, R.I.; Hung, S.K.; Chuang, Y.M.; Wu, S.F.; et al. Epigenetic silencing of the dual-role signal mediator, ANGPTL4 in tumor tissues and its overexpression in the urothelial carcinoma microenvironment. Oncogene 2018, 37, 673-686. [CrossRef] [PubMed]

147. Kolb, R.; Kluz, P.; Tan, Z.W.; Borcherding, N.; Bormann, N.; Vishwakarma, A.; Balcziak, L.; Zhu, P.; Davies, B.S.; Gourronc, F.; et al. Obesity-associated inflammation promotes angiogenesis and breast cancer via angiopoietin-like 4. Oncogene 2019, 38, $2351-2363$. [CrossRef]

148. Goh, Y.Y.; Pal, M.; Chong, H.C.; Zhu, P.; Tan, M.J.; Punugu, L.; Lam, C.R.; Yau, Y.H.; Tan, C.K.; Huang, R.L.; et al. Angiopoietin-like 4 interacts with integrins beta1 and beta5 to modulate keratinocyte migration. Am. J. Pathol. 2010, 177, 2791-2803. [CrossRef] [PubMed]

149. Huang, R.L.; Teo, Z.; Chong, H.C.; Zhu, P.; Tan, M.J.; Tan, C.K.; Lam, C.R.; Sng, M.K.; Leong, D.T.; Tan, S.M.; et al. ANGPTL4 modulates vascular junction integrity by integrin signaling and disruption of intercellular VE-cadherin and claudin- 5 clusters. Blood 2011, 118, 3990-4002. [CrossRef] [PubMed] 
150. Goh, Y.Y.; Pal, M.; Chong, H.C.; Zhu, P.; Tan, M.J.; Punugu, L.; Tan, C.K.; Huang, R.L.; Sze, S.K.; Tang, M.B.; et al. Angiopoietin-like 4 interacts with matrix proteins to modulate wound healing. J. Biol. Chem. 2010, 285, 32999-33009. [CrossRef] [PubMed]

151. Nakayama, T.; Hirakawa, H.; Shibata, K.; Nazneen, A.; Abe, K.; Nagayasu, T.; Taguchi, T. Expression of angiopoietin-like 4 (ANGPTL4) in human colorectal cancer: ANGPTL4 promotes venous invasion and distant metastasis. Oncol. Rep. 2011, 25, 929-935. [CrossRef] [PubMed]

152. Ma, T.; Jham, B.C.; Hu, J.; Friedman, E.R.; Basile, J.R.; Molinolo, A.; Sodhi, A.; Montaner, S. Viral G protein-coupled receptor up-regulates Angiopoietin-like 4 promoting angiogenesis and vascular permeability in Kaposi's sarcoma. Proc. Natl. Acad. Sci. USA 2010, 107, 14363-14368. [CrossRef] [PubMed]

153. Huang, X.F.; Han, J.; Hu, X.T.; He, C. Mechanisms involved in biological behavior changes associated with Angptl4 expression in colon cancer cell lines. Oncol. Rep. 2012, 27, 1541-1547.

154. Zhu, P.; Tan, M.J.; Huang, R.L.; Tan, C.K.; Chong, H.C.; Pal, M.; Lam, C.R.; Boukamp, P.; Pan, J.Y.; Tan, S.H.; et al. Angiopoietin-like 4 protein elevates the prosurvival intracellular $\mathrm{O} 2(-): \mathrm{H} 2 \mathrm{O} 2$ ratio and confers anoikis resistance to tumors. Cancer Cell 2011, 19, 401-415. [CrossRef]

155. Baba, K.; Kitajima, Y.; Miyake, S.; Nakamura, J.; Wakiyama, K.; Sato, H.; Okuyama, K.; Kitagawa, H.; Tanaka, T.; Hiraki, M.; et al. Hypoxia-induced ANGPTL4 sustains tumour growth and anoikis resistance through different mechanisms in scirrhous gastric cancer cell lines. Sci. Rep. 2017, 7, 11127. [CrossRef] [PubMed]

156. Liao, Y.H.; Chiang, K.H.; Shieh, J.M.; Huang, C.R.; Shen, C.J.; Huang, W.C.; Chen, B.K. Epidermal growth factor-induced ANGPTL4 enhances anoikis resistance and tumour metastasis in head and neck squamous cell carcinoma. Oncogene 2017, 36, 2228-2242. [CrossRef]

157. Jung, K.H.; Son, M.K.; Yan, H.H.; Fang, Z.; Kim, J.; Kim, S.J.; Park, J.H.; Lee, J.E.; Yoon, Y.C.; Seo, M.S.; et al. ANGPTL4 exacerbates pancreatitis by augmenting acinar cell injury through upregulation of C5a. EMBO Mol. Med. 2020, 12, e11222. [CrossRef]

158. Zhao, T.; Du, H.; Blum, J.S.; Yan, C. Critical role of PPARgamma in myeloid-derived suppressor cell-stimulated cancer cell proliferation and metastasis. Oncotarget 2016, 7, 1529-1543. [CrossRef]

159. Li, H.; Sorenson, A.L.; Poczobutt, J.; Amin, J.; Joyal, T.; Sullivan, T.; Crossno, J.T., Jr.; Weiser-Evans, M.C.; Nemenoff, R.A. Activation of PPARgamma in myeloid cells promotes lung cancer progression and metastasis. PLoS ONE 2011, 6, e28133. [CrossRef] [PubMed]

160. Sippel, T.R.; Johnson, A.M.; Li, H.Y.; Hanson, D.; Nguyen, T.T.; Bullock, B.L.; Poczobutt, J.M.; Kwak, J.W.; Kleczko, E.K.; Weiser-Evans, M.C.; et al. Activation of PPARgamma in Myeloid Cells Promotes Progression of Epithelial Lung Tumors through TGFbeta1. Mol. Cancer Res. 2019, 17, 1748-1758. [CrossRef] [PubMed]

161. Zou, Y.; Watters, A.; Cheng, N.; Perry, C.E.; Xu, K.; Alicea, G.M.; Parris, J.L.D.; Baraban, E.; Ray, P.; Nayak, A.; et al. Polyunsaturated Fatty Acids from Astrocytes Activate PPARgamma Signaling in Cancer Cells to Promote Brain Metastasis. Cancer Discov. 2019, 9, 1720-1735. [CrossRef] [PubMed]

162. Gong, X.; Hou, Z.; Endsley, M.P.; Gronseth, E.I.; Rarick, K.R.; Jorns, J.M.; Yang, Q.; Du, Z.; Yan, K.; Bordas, M.L.; et al. Interaction of tumor cells and astrocytes promotes breast cancer brain metastases through TGF- $\beta 2 /$ ANGPTL4 axes. NPJ Precis. Oncol. 2019, 3, 24. [CrossRef] [PubMed]

163. Youssef, J.; Badr, M. Peroxisome proliferator-activated receptors and cancer: Challenges and opportunities. Br. J. Pharmacol. 2011, 164, 68-82. [CrossRef]

164. Xi, Y.; Zhang, Y.; Zhu, S.; Luo, Y.; Xu, P.; Huang, Z. PPAR-Mediated Toxicology and Applied Pharmacology. Cells 2020, 9 , 352. [CrossRef]

165. Plutzky, J. The PPAR-RXR transcriptional complex in the vasculature: Energy in the balance. Circ. Res. 2011, 108, 1002-1016. [CrossRef] [PubMed]

166. Fulton, J.; Mazumder, B.; Whitchurch, J.B.; Monteiro, C.J.; Collins, H.M.; Chan, C.M.; Clemente, M.P.; Hernandez-Quiles, M.; Stewart, E.A.; Amoaku, W.M.; et al. Heterodimers of photoreceptor-specific nuclear receptor (PNR/NR2E3) and peroxisome proliferator-activated receptor-gamma (PPARgamma) are disrupted by retinal disease-associated mutations. Cell. Death. Dis. 2017, 8, e2677. [CrossRef] [PubMed]

167. De Bosscher, K.; Desmet, S.J.; Clarisse, D.; Estebanez-Perpina, E.; Brunsveld, L. Nuclear receptor crosstalk-defining the mechanisms for therapeutic innovation. Nat. Rev. Endocrinol. 2020, 16, 363-377. [CrossRef] [PubMed]

168. Thomas, R.G.; Surendran, S.P.; Jeong, Y.Y. Tumor Microenvironment-Stimuli Responsive Nanoparticles for Anticancer Therapy. Front. Mol. Biosci. 2020, 7, 610533. [CrossRef] [PubMed]

169. Lutz, H.; Hu, S.; Dinh, P.-U.; Cheng, K. Cells and cell derivatives as drug carriers for targeted delivery. Med. Drug Discov. 2019, 3, 100014. [CrossRef]

170. Zhang, X.; Wang, C.; Wang, J.; Hu, Q.; Langworthy, B.; Ye, Y.; Sun, W.; Lin, J.; Wang, T.; Fine, J.; et al. PD-1 Blockade Cellular Vesicles for Cancer Immunotherapy. Adv. Mater. 2018, 30, e1707112. [CrossRef] [PubMed]

171. Tian, Y.; Li, S.; Song, J.; Ji, T.; Zhu, M.; Anderson, G.J.; Wei, J.; Nie, G. A doxorubicin delivery platform using engineered natural membrane vesicle exosomes for targeted tumor therapy. Biomaterials 2014, 35, 2383-2390. [CrossRef] [PubMed]

172. Kim, M.S.; Haney, M.J.; Zhao, Y.; Mahajan, V.; Deygen, I.; Klyachko, N.L.; Inskoe, E.; Piroyan, A.; Sokolsky, M.; Okolie, O.; et al. Development of exosome-encapsulated paclitaxel to overcome MDR in cancer cells. Nanomedicine 2016, 12, 655-664. [CrossRef] 
173. Subra, C.; Grand, D.; Laulagnier, K.; Stella, A.; Lambeau, G.; Paillasse, M.; De Medina, P.; Monsarrat, B.; Perret, B.; Silvente-Poirot, S.; et al. Exosomes account for vesicle-mediated transcellular transport of activatable phospholipases and prostaglandins. J. Lipid Res. 2010, 51, 2105-2120. [CrossRef] [PubMed]

174. He, Q.; Chen, J.; Yan, J.; Cai, S.; Xiong, H.; Liu, Y.; Peng, D.; Mo, M.; Liu, Z. Tumor microenvironment responsive drug delivery systems. Asian J. Pharm. Sci. 2020, 15, 416-448. [CrossRef] [PubMed]

175. Sun, Q.; Zhou, Z.; Qiu, N.; Shen, Y. Rational Design of Cancer Nanomedicine: Nanoproperty Integration and Synchronization. Adv. Mater. 2017, 29, 1606628. [CrossRef] [PubMed]

176. Ricci, M.; Miola, M.; Multari, C.; Borroni, E.; Canuto, R.A.; Congiusta, N.; Verne, E.; Follenzi, A.; Muzio, G. PPARs are mediators of anti-cancer properties of superparamagnetic iron oxide nanoparticles (SPIONs) functionalized with conjugated linoleic acid. Chem. Biol. Interact. 2018, 292, 9-14. [CrossRef] [PubMed]

177. Koczorowska, M.M.; Tholen, S.; Bucher, F.; Lutz, L.; Kizhakkedathu, J.N.; De Wever, O.; Wellner, U.F.; Biniossek, M.L.; Stahl, A.; Lassmann, S.; et al. Fibroblast activation protein-alpha, a stromal cell surface protease, shapes key features of cancer associated fibroblasts through proteome and degradome alterations. Mol. Oncol. 2016, 10, 40-58. [CrossRef]

178. Hofheinz, R.D.; al-Batran, S.E.; Hartmann, F.; Hartung, G.; Jager, D.; Renner, C.; Tanswell, P.; Kunz, U.; Amelsberg, A.; Kuthan, H.; et al. Stromal antigen targeting by a humanised monoclonal antibody: An early phase II trial of sibrotuzumab in patients with metastatic colorectal cancer. Onkologie 2003, 26, 44-48. [CrossRef]

179. Narra, K.; Mullins, S.R.; Lee, H.O.; Strzemkowski-Brun, B.; Magalong, K.; Christiansen, V.J.; McKee, P.A.; Egleston, B.; Cohen, S.J.; Weiner, L.M.; et al. Phase II trial of single agent Val-boroPro (Talabostat) inhibiting Fibroblast Activation Protein in patients with metastatic colorectal cancer. Cancer Biol. Ther. 2007, 6, 1691-1699. [CrossRef]

180. Kallenberg, D.; Tripathi, V.; Javaid, F.; Pilotti, C.; George, J.; Davis, S.; Blackburn, J.W.; O'Connor, M.; Dowsett, L.; Bowers, C.E.; et al. A Humanized Antibody against LRG1 that Inhibits Angiogenesis and Reduces Retinal Vascular Leakage. bioRxiv 2020. [CrossRef] 